CUADERNOS DE ESTUDIOS GALLEGOS, LXII Núm. 128 (enero-diciembre 2015), págs. 107-139

ISSN: $0210-847 \mathrm{X}$

DOI: 10.3989/ceg.2015.128.04

\title{
LA ESCRIBANÍA DE LAS JUNTAS DEL REINO DE GALICIA (1599-1834)*
}

\author{
Gonzalo Francisco Fernández SuÁrez \\ Universidad de Santiago de Compostela
}

* El presente texto se enmarca en el proyecto de investigación "Linaje, parentela y poder: la pirámide nobiliaria gallega (siglos XIII al XV) (II)" (MINECO, Plan Estatal de Investigación Científica y Técnica y de Innovación 2013-2016. Ref. HAR2013-42985-P), del que es investigador principal el Dr. Eduardo Pardo de Guevara y Valdés. 


\section{LA ESCRIBANÍA DE LAS JUNTAS DEL REINO DE GALICIA (1599-1834)}

\section{RESUMEN}

Este artículo tiene por objetivo estudiar la escribanía de las Juntas del Reino de Galicia. Para ello se ha tomado como base la documentación relativa a las Juntas del Reino de Galicia que se conserva para el período temporal comprendido entre los años 1599 y 1834 . El trabajo se inicia con un análisis de las fuentes conservadas para pasar a continuación a abordar, en diferentes apartados, cuestiones tales como el origen de la escribanía de las juntas, el sistema de nombramiento de sus titulares y los requisitos exigidos, sus funciones, el sistema de remuneración y finalmente su origen geográfico y perfil profesional.

Palabras Clave: Juntas del Reino de Galicia, escribanía, 1599-1834, Reino de Galicia.

\section{A ESCRIBANÍA DAS XUNTAS DO REINO DE GALICIA (1599-1834)}

\section{RESUMO}

Este artigo ten por obxetivo estudiar a escribanía das Xuntas do Reino de Galicia. Para isto tomouse como base a documentación relativa ás Xuntas do Reino de Galicia que se conserva para o período temporal comprendido entre os anos 1599 e 1834. O traballo iníciase cunha análise das fontes conservadas para pasar a continuación a abordar, en diferentes apartados, cuestións tales como a orixe da escribanía das xuntas, o sistema de nomeamento dos seus titulares e os requisitos esixidos, as súas funcións, o sistema de remuneración e finalmente a súa orixe xeográfica e perfil profesional.

Palabras clave: Xuntas do Reino de Galicia, escribanía, 1599-1834, Reino de Galicia.

\section{THE OFFICIAL WRITINGS OF THE COUNCILS OF THE REALM OF GALICIA} (1599-1834)

\section{AbStract}

This article aims to study the official writings of the Board of the Realm of Galicia. It is based on the documentation of the Board of the Realm of Galicia preserved nowadays, for the time period between 1599 and 1834. The paper begins with an analysis of the preserved sources, addressing later on, in different sections, issues such as the origin of the office of the Board, the system of appointment of its members as well as the requirements, functions, remuneration system and finally their geographical origin and professional profile.

KeY words: Meetings of the Board of the Realm of Galicia, Documentation 1599-1834, Realm of Galicia. 
Recibido/Received: 08/04/2015

Aceptado/Accepted: 06/07/2015

LAS FUENTES DOCUMENTALES PARA EL ESTUDIO DE LA ESCRIBANÍA DE LA JUNTA DE REINO

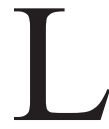

as únicas fuentes documentales existentes para el estudio de la escribanía de las juntas del Reino de Galicia son los libros de acuerdos de las mismas. Estos libros se custodian en los archivos municipales de las siete antiguas capitales provinciales, archivos históricos provinciales y en el Archivo del Reino de Galicia, existiendo notables diferencias de unos a otros en cuanto al número de libros conservados, el hecho de si son originales o copias, su estado de conservación y la existencia o no de otra documentación complementaria ${ }^{1}$. A todo esto hay que añadir que una parte de estos fondos ha sufrido una reubicación en fechas recientes ${ }^{2}$. El total de reuniones a las que concurrieron los representantes de las antiguas provincias gallegas y de las que ha quedado testimonio escrito desde 1599 -primer año del que se conserva un libro de acuerdos- hasta 1834 -año en el que se celebra la última- alcanza las 113. En la actualidad todas ellas se han editado dentro de un proyecto que ha culminado en el año 2010 con la publicación del volumen $\mathrm{XXVII}^{3}$.

\footnotetext{
1 Sobre la localización y recuento de los libros de las actas de las juntas y resto de documentación remitimos al lector al artículo de María del Rosario Matilde Varela Pardo y María Luz Rama PATIÑo, "Informe sobre la documentación de juntas del Reino catalogada en los archivos públicos de las siete antiguas ciudades del Reino de Galicia", en Antonio Eiras Roel (ed.), Actas de las Juntas del Reino de Galicia, vol. 1, Santiago de Compostela, Dirección Xeral do Patrimonio Histórico e Documental, 1995, págs. 87-157.

2 El 1 de octubre de 2012 el Archivo Histórico Provincial de Pontevedra hizo entrega al ayuntamiento de Tui de la documentación histórica de este concejo depositada en dicho archivo desde 1943. En total se devolvieron al archivo municipal de esta ciudad 145 libros entre los cuales figuraban los libros de las Juntas del Reino de Galicia. Arquivos De Galicia [en línea], disponible en <http:// arquivosdegalicia.xunta.es/portal/arquivo-historico-provincial-de pontevedra/content/actividades/ actualidad/actual_0002.html?lang=es> [Consulta: 02/12/2014].

3 El proceso de edición de las juntas del Reino de Galicia, iniciado bajo el impulso del presidente de la Xunta de Galicia, don Manuel Fraga Iribarne, en 1995, sería dirigido hasta el volumen 15 por el profesor don Antonio Eiras Roel, catedrático de Historia Moderna de la Universidad de Santiago. Los restantes volúmenes, del 16 al 27, bajo el título de Xuntas do Reino de Galicia: actas, serían editados bajo la dirección del profesor don Miguel Romaní Martínez, catedrático de Ciencias y Técnicas Historiográficas de la Universidad de Santiago.
} 
Las noticias sobre la escribanía se encuentran entremezcladas con el resto de temas abordados durante las sesiones de trabajo de los diputados de las juntas, quedando consignados todos ellos en el acta correspondiente. Ello nos ha obligado a revisarlas una a una en búsqueda de cualquier indicio cuya reiteración a lo largo de los años nos pusiera sobre la pista del modo y las variaciones experimentadas en la provisión de este oficio, las tareas que tenía encomendadas su titular, la identidad de cada uno, su categoría profesional y origen geográfico, etc. Junto a estas actas se hallan otros documentos, emanados de la propia Junta, de particulares o bien de la Corona, tales como representaciones, provisiones reales, memoriales, etc., en especial, entre los años 1639 y 1703 y cuya aparición durante este lapso temporal hay que vincularla, como luego veremos, con el proceso de patrimonialización sufrido por este oficio y las pruebas documentales aportadas para apoyar o contradecir las demandas de las partes enfrentadas.

\section{El origen de la ESCRIBANÍA de las Juntas del ReINo de Galicia}

Dada la inexistencia de actas de las juntas de Reino con anterioridad al año 1599, resulta complicado, cuando no imposible, establecer cualquier periodización aproximada acerca del nacimiento e instauración de su escribanía. Autores como Benito Vicetto, Manuel Murguía o Pablo Pérez Costanti han pasado por alto esta cuestión, limitándose a indicar el supuesto momento de su instauración, algunas de sus convocatorias más destacadas o a recrear la ceremonia de su constitución ${ }^{4}$. Cercanas en el tiempo y más rigurosas en cuanto a la metodología aplicada al análisis de las fuentes y resultados obtenidos, son otras aportaciones que han destacado el proceso evolutivo operado en esta institución durante la Edad Moderna y su papel dentro del organigrama político-administrativo y hacendístico de la Corona de Castilla $^{5}$. La primera referencia a una fecha exacta aparece citada en la obra de Enrique Fernández-Villamil y Alegre, quien erróneamente transcribe el nombre de Fernando de Granada, en lugar de Fernando de Gamarra, como el primer escribano documentado en la Junta de septiembre-octubre de $1608^{6}$. Sin

\footnotetext{
4 Benito Vicetto, Historia de Galicia, vol. 7, Ferrol, pág. 11; Manuel Murguía, Galicia, vol. 1, Vigo, Edicións Xerais de Galicia, 1982, págs. 297-304 o Pablo Pérez Costanti, Notas viejas galicianas, vol. 1, Vigo, Imprenta de los Sindicatos Católicos, 1925, págs. 14-26.

5 Véase a Antonio Eiras Roel, "Introducción histórica: las Juntas del Reino de Galicia en el período protoinstitucional, 1599-1629”, en Antonio Eiras Roel (ed.), Actas de las Juntas..., vol. 1, págs. 5-55; Laura Fernández Vega, "Orígenes y antecedentes, naturaleza y función de las juntas del Reino de Galicia, hasta la consecución del voto en Cortes", en Antonio Eiras Roel (ed.), Actas de las Juntas..., vol. 1, págs. 59-85; Manuel María de ArTAZA Montero, Rey, reino y representación: la Junta General del Reino de Galicia (1599-1834), Madrid, Consejo Superior de Investigaciones Científicas, 1998. 6 Juntas del Reino de Galicia: historia de su nacimiento, actuaciones y extinción, vol. 2, Madrid, Instituto de Estudios Políticos, 1962, pág. 58.
} 
embargo, si tomamos como punto de partida la primera Junta conservada del año 1599, concluiremos que este oficio había recaído en Antonio García Salgado, secretario del ayuntamiento de A Coruña, quien es nombrado el 17 de febrero de 15997, fecha esta que también Artaza Montero acepta al analizar el origen geográfico de estos profesionales hasta la tercera década del siglo XVII ${ }^{8}$. De modo general, y a tenor de las noticias extraídas de la documentación conservada posteriormente, podemos concluir que su aparición se vincula estrechamente a los años desde los que se empiezan a registrar por escrito y de manera sistemática las actas de las reuniones de la Junta de Reino. Sería, por lo tanto, la necesidad primordial de dejar constancia de lo tratado y acordado en sus reuniones lo que explicaría su inclusión dentro del organigrama funcional de esta institución.

El nombramiento de los escribanos de las Juntas del Reino de Galicia Y LOS REQUISITOS EXIGIDOS

\section{El sistema de nombramiento}

A lo largo del período de tiempo que abarca este estudio, la prerrogativa de nombrar a los escribanos de las juntas sufrió varias modificaciones ${ }^{9}$ de acuerdo con las propias decisiones adoptadas por los representantes del Reino, otras de las que ignoramos sus motivaciones o al verse afectada por la política de venta de cargos llevada a cabo por la propia Corona $^{10}$, pudiendo distinguirse varias etapas en esta evolución.

Una primera etapa comprende las juntas desde el año 1599 hasta la de septiembre-octubre de 1633 y se caracteriza por ser los propios diputados del Reino quienes proveen la escribanía. Tras iniciarse la reunión ${ }^{11}$, una de las primeras

\footnotetext{
Antonio Eiras Roel (ed.), Actas de las Juntas..., vol. 1, pág. 163.

8 Manuel María de Artaza Montero: Rey, Reino y..., pág. 158.

9 Un proceso parecido podemos verlo también en la escribanía de la Junta General del Principado de Asturias. Alfonso Menéndez GonzÁlez, Élite y poder: la Junta General del Principado de Asturias, 1594-1808, Oviedo, Instituto de Estudios Asturianos, 1992, pág. 203. Una versión más amplia en Marta Friera Álvarez, La Junta General del Principado de Asturias a fines del Antiguo Régimen (1760-1835), Oviedo, Junta General del Principado de Asturias, 2003, págs. 124-125.

${ }^{10}$ Una buena síntesis en Antonio Domínguez OrTiz, "La venta de cargos y oficios públicos en Castilla y sus consecuencias económicas y sociales", en Antonio Domínguez Ortiz, Instituciones y sociedad en la España de los Austrias, Barcelona, Ariel, 1985, págs. 145-183; Francisco Tomás y Valiente, "Ventas de oficios públicos en Castilla durante los siglos XVII y XVIII", en Francisco Tomás y Valiente, Gobierno e instituciones en la España del Antiguo Régimen, Madrid, Alianza, 1982, págs. 151-177.

${ }^{11}$ Relación completa sobre la convocatoria, estilo de celebración y disolución de las juntas en Enrique Fernández-Villamil Alegre, Juntas del Reino de Galicia:..., vol. 2, págs. 79-176. Versión más
} 
tareas de los representantes de las provincias consistía en designar al personal subalterno que debería asistirles en sus salidas públicas y resto de asuntos que les encomendasen. Este personal subalterno estaba formado por el alguacil mayor, entre dos y cuatro porteros y maceros y el escribano ${ }^{12}$. Por norma general la designación del escribano, al igual que el resto de dependientes, tenía lugar en la primera conferencia, una vez examinadas y aceptadas las cartas de poder que cada diputado traía de su ciudad. Prueba de ello es que de las 22 convocatorias que tuvieron lugar entre las fechas anteriormente citadas, en 18 de ellas el escribano fue designado en la primera conferencia, en 3 en la segunda y en solo 1 en la quinta. Este pequeño retraso guarda relación con ciertas formalidades practicadas previamente como la petición o recepción de los representantes del Reino en audiencia por parte del Gobernador en las juntas de septiembre-octubre de 1608, diciembre de 1613 y julio de $1629^{13}$; o bien, caso de la Junta de junio-julio de 1624 , por haber abordado en cuatro sesiones de modo particular el horario de las sesiones y la presentación de poderes, la convocatoria del Reino, la propuesta del tema a tratarse y el acuerdo para que las credenciales extendidas a los diputados tuviesen las mismas cláusulas ${ }^{14}$. En cuanto a la fórmula empleada, las actas se limitan a señalar que se trataba de un acuerdo unánime "de conformidad" de los siete procuradores de las ciudades, pero sin ofrecer otros detalles tales como los debates a los que daban lugar durante las reuniones o la existencia de bandos que apoyaban diferentes candidaturas ${ }^{15}$. Sin embargo, hemos comprobado que ni siquiera la discrepancia de alguno de los representantes en cuanto al candidato elegido, era motivo suficiente para declarar invalidada una elección. Una prueba de esto la encontramos en el nombramiento de Antonio de Cea Mariño como escribano de la Junta de febrero de 1636 y al que se oponía don Alonso Gómez, procurador de la ciudad de A Coruña, al haberse hecho estando presente el mismo aspirante y no contar con su beneplácito. Pese a esto, el resto de representantes

reducida en Laura FERNÁNDEZ VEGA, “Orígenes y antecedentes, naturaleza y función de las juntas del Reino de Galicia, hasta la consecución del voto en Cortes", en Antonio Eiras Roel (ed.), Actas de las Juntas..., vol. 1, págs. 69-71.

12 Enrique Fernández-VIllamil y Alegre, Juntas del Reino de Galicia:..., vol. 2, págs. 71-75.

13 Véase para cada caso Antonio Eiras Roel (ed.), Actas de las Juntas..., vol. 1, págs. 183-184, $198-199$ y $410-411$.

14 Ibídem, págs. 255-258.

${ }^{15}$ Un ejemplo de la existencia de estos bandos, podemos verlo en la corporación lucense en el año 1627 en el momento de proceder a la elección de Juan Sanjurjo y Aguiar como escribano del concejo. Gonzalo Francisco Fernández SuÁrez, "Una primera aproximación a los escribanos del concejo de Lugo entre los siglos XVI-XVIII”, en Carlos Baliñas Pérez, Gonzalo Francisco Fernández Suárez (eds.), Sur Urbem: historia, sociedade e cultura da cidade, Santiago de Compostela, Universidade de Santiago de Compostela, 2012, págs. 151-152. 
hicieron valer su mayoría para ratificar al citado Antonio de Cea Mariño en el oficio $^{16}$.

Este sistema se mantendría de manera invariable hasta la Junta de septiembre-octubre de 1633 en cuya sesión del 7 de octubre se adoptaría una nueva modalidad para la provisión de la escribanía de la Junta de Reino. Esta mutación había tenido su punto de partida en la propuesta realizada por don Fernando Ozores, regidor de Santiago de Compostela, quien había sugerido que la ciudad que estuviese en posesión del arca de los arbitrios, fuese también quien se encargase de nombrar al mismo escribano. Una vez examinada con detenimiento, el conjunto de representantes acordaron por unanimidad mudar el procedimiento empleado. Desde entonces el nombramiento se realizaría por turno, principiando por la ciudad de Santiago de Compostela y continuando por las de Betanzos, A Coruña, Mondoñedo, Lugo, Ourense y Tui. Cada una de ellas debería designar al escribano antes de comenzar la reunión, y, de no hacerlo, sería su procurador quien lo haría al llegar a la población señalada para la celebración de la junta. Las razones para este cambio no aparecen del todo clarificadas, pues en el acuerdo adoptado solo se alude de manera vaga a las controversias surgidas sobre el modo de nombrar al escribano ${ }^{17}$. Artaza Montero apunta como posible desencadenante el intento de monopolización del oficio por parte de sus titulares, coruñeses en su mayoría hasta principios de la década de los años 30 del siglo XVII ${ }^{18}$.

Este modelo "turnario" se pondría en funcionamiento en la Junta de abril-mayo de 1634, correspondiendo el nombramiento a la ciudad de Betanzos en la persona de Antonio Sobrino de Parga ${ }^{19}$, al haber renunciado a su turno la de Santiago de Compostela en la reunión anterior ${ }^{20}$. Sin embargo, tras la siguiente convocatoria de mayo de ese mismo año cuando ejerce su vez el concejo coruñés ${ }^{21}$, se retornaría al método anterior a partir de la Junta de mayo-julio de 1635, prolongándose hasta comienzos de la de diciembre de 1649-julio de 1650. Las motivaciones de esta repentina alteración, nos son totalmente desconocidas por dos razones. En primer lugar, sabemos que entre la reunión de mayo de 1634 y la de mayo-julio de 1635, había tenido lugar otra que se había clausurado el 23 de febrero de 1635,

\footnotetext{
${ }^{16}$ Texto completo en Eiras Roel (ed.), Actas de las Juntas..., vol. 1, pág. 355.

${ }^{17}$ Antonio Eiras Roel (ed.), Actas de las Juntas..., vol. 2, pág. 149.

${ }^{18}$ Vid. de este autor Rey, Reino y ..., pág. 158.

${ }^{19}$ Antonio Eiras Roel (ed.), Actas de las Juntas..., vol. 2, pág. 156.

${ }^{20}$ Tras la fijación de los turnos de nombramiento, se había acordado que comenzasen "... por la ciudad de Vetanços, y tras della la çiudad de la Coruña, y luego Mondeñedo y Lugo y después Orense y Tui, por quanto la çiudad de Santiago, por esta ves, renunció su turno, para que entren todos, y después de acabado se comience por la çiudad de Santiago y se vaya siguiendo como queda hordenado." Antonio Eiras Roel (ed.), Actas de las Juntas..., vol. 2, pág. 149.

${ }^{21}$ Ibídem, pág. 208.
} 
tal y como se indica en la sesión inaugural de la de mayo-julio de $1635^{22}$, y de la que no se han conservado sus actas ${ }^{23}$ con lo que desconocemos las hipotéticas decisiones que pudieron adoptarse sobre esta materia. Del mismo modo los libros de consistorio de la ciudad de Mondoñedo, a la que le tocaba por turno nombrar al escribano, eluden cualquier mención sobre este asunto, limitándose a informar de la recepción de una carta remitida por el Marqués de Mancera, Gobernador del Reino, en la que ordena al concejo mindoniense que envíe a un regidor para continuar la Junta que se había suspendido en el mes de febrero pasado y a recoger de manera pormenorizada el parecer y el voto emitido por cada munícipe en la elección de don Pedro de Saavedra como diputado ${ }^{24}$.

A lo largo de casi dos décadas, la elección del escribano recaería de manera invariable en una decisión mayoritaria y consensuada de los representantes de cada ciudad que, en algunas ocasiones, se limitaron a confirmar ${ }^{25}$ a un mismo individuo para ciertos períodos de tiempo o bien a designarle vitaliciamente ${ }^{26}$. Será, como ya hemos apuntado, durante la Junta de diciembre de 1649-julio de 1650 cuando asistamos a una nueva reforma del uso vigente hasta entonces. Tomando como argumento el legítimo derecho que el Reino tenía sobre el modo de proveer dicho oficio, se decidió que a partir de entonces su ejercicio recayese en manos de los escribanos de los ayuntamientos de las siete capitales de provincia a quienes, en atención al trabajo que desempeñaban en sus respectivas corporaciones municipales, se les dispensaba el honor de gozar de este empleo. El procedimiento empleado desde esta fecha, se basaría en el orden de precedencias observado en la ceremonia de las salidas públicas de los diputados del Reino ${ }^{27}$. De acuerdo con esto y al convocarse una nueva junta, cada ciudad nombraría por turno al escribano, comenzando por la de Santiago de Compostela y prosi-

\footnotetext{
${ }^{22}$ De hecho esta nueva reunión tenía como objeto “... proseguir la Junta que se suspendió últimamente, en veinte y tres del mes de ebrero passado deste pressente año,..." Antonio Eiras Roel (ed.), Actas de las Juntas..., vol. 2, pág. 230.

${ }^{23}$ El número total de juntas conservadas entre 1599 y 1834 asciende a 113. Enumeración detallada por María del Rosario Matilde Varela Pardo y María Luz Rama Patiño "Informe sobre la documentación de Juntas de Reino...”, págs. 91-157.

${ }^{24}$ Archivo Municipal de Mondoñedo, Libros de consistorio, Libro 925, fols. 166r.-169r.

${ }^{25}$ Un ejemplo de la continuidad de un mismo titular a lo largo de varios años lo encontramos en Diego del Río a quien se había confirmado su nombramiento en la Junta de noviembre de 1638-febrero de 1639, repitiendo en la de marzo-abril de 1639 y principios de la de enero-febrero de 1640. Antonio Eiras Roel (ed.), Actas de las Juntas..., vol. 3, págs. 345 y 400 y vol. 4, pág. 62, respectivamente. ${ }^{26}$ Jorge das Seixas quien venía ejerciendo como escribano de manera casi ininterrumpida desde la Junta de enero-febrero de 1640, había sido designado de manera vitalicia en la de marzo-mayo de 1644, ejerciendo como tal hasta la de noviembre de 1648-febrero de 1649. Vid. Antonio EIRAs RoEL (ed.), Actas de las Juntas..., vol. 5, pág. 208.

${ }^{27}$ Ritual descrito con un gráfico del mismo en Enrique Fernández-Villamil y Alegre, Juntas del Reino de Galicia:..., vol. 2, págs. 94-99.
} 
guiendo por las de A Coruña, Betanzos, Lugo, Mondoñedo, Ourense y Tui ${ }^{28}$. Y a fin de evitar variaciones que en lo sucesivo pudiesen causar algún obstáculo, se suplicaría al monarca que expidiese una real cédula confirmando este acuerdo ${ }^{29}$. Desde entonces la designación del escribano por cada ciudad sería una constante hasta la Junta de septiembre de 1677-septiembre de 1678, con las excepciones de la Junta de febrero-marzo de 1665 y de la de febrero-marzo de 1669 en las cuales sería el Reino quien lo nombraría. En el primer caso, el nombramiento de Pedro Rodríguez de Leis por el Reino tal vez estuvo motivado por el hecho de haber renunciado la ciudad de Ourense a su vez, ya que en la siguiente Junta de septiembre-octubre de 1666 es la ciudad de Tui quien designa al nuevo escribano. Por el contrario, resulta imposible dar una explicación satisfactoria sobre el motivo o motivos que impulsaron a los representantes de las siete provincias a escoger a Pedro Pérez de Caxide para la mencionada Junta de febrero-marzo de 1669. El único testimonio del que disponemos es el acuerdo adoptado durante su inicio el 9 de febrero de 1669 y que insistía en que dicho nombramiento no hiciera correr el turno de ninguna ciudad electora ${ }^{30}$.

\section{La venta de la escribanía de las juntas del Reino}

Pese a las precauciones del Reino por mantener la prerrogativa de nombrar al escribano, poniendo en marcha diversas estrategias como ya hemos comentado, esto no evitaría que dicho oficio acabase siendo enajenado y, en consecuencia, patrimonializado en manos particulares. Sin embargo, lejos de ser un hecho puntual, la venta de la escribanía se acabaría convirtiendo en algo dilatado y que se fue complicando con el transcurso de los años, porque los representantes de las provincias intentaron evitar en lo posible la toma de posesión de su comprador negándole taxativamente su uso, forzando constantes apelaciones a fin de ahogar económicamente al comprador u ofreciéndose a devolver la suma abonada en el momento de su compra.

Si damos crédito al memorial que Juan Becerra de Piñeiro, Secretario de Guerra del Reino de Galicia, afirmaba haber aportado en la Junta de noviembre de 1638-febrero de 1639, las primeras tentativas de adquisición de la escribanía de las juntas hay que enclavarlas en una decisión de los propios diputados del Reino.

\footnotetext{
${ }^{28}$ La enumeración de los diputados presentes en cada reunión también se realizaba siguiendo este mismo orden en la intitulación de cada nueva acta.

${ }^{29}$ Antonio Eiras Roel (ed.), Actas de las Juntas..., vol. 6, págs. 131-132.

30 " $Y$ luego dichos señores dijeron que para esta Junta nombravan a mí, scrivano, por scrivano della hasta que se desuelba, sin ser bisto causar ningún turno a la çiudad a quien toca esta Junta para que en la primera, sin que ésta perjudique a ninguna, nombre la a quien tocare en la primera Junta que se ofrezca." Antonio Eiras Roel (ed.), Actas de las Juntas..., vol. 8, pág. 93.
} 
De acuerdo con este memorial, Juan Becerra de Piñeiro quien en fecha desconocida había sido nombrado escribano de las juntas venideras, habría suplicado a la Corona que le despachase y confirmase este título, junto con las distinciones que llevaba aparejadas. Y para apoyar más esta pretensión, solicitaba al Reino cartas recomendatorias a su favor dirigidas a su Magestad, el Conde-Duque de Olivares y señores procuradores de Cortes. Aunque dicha instancia contó con el respaldo de la mayoría de los presentes, don Antonio Guillamás, diputado de A Coruña, y don Juan de Cadaval y Aldao, diputado de Ourense, manifestaron su rechazo a ésta, matizando que esta recomendación debería contemplar que el nombramiento se le hiciese vitaliciamente y no a perpetuidad, dado el perjuicio que, según ellos, supondría para el Reino esta decisión ${ }^{31}$.

Este, por así decirlo, intento de dotar a la escribanía de un carácter más oficial, al proveerla de un titular fijo, quien recibiría el título acreditativo de la Corona y gozaría de los honores que llevaba implícito, puede encuadrarse, al menos teóricamente, dentro del proceso de transformación sufrido por la propia Junta de Reino desde la segunda década del siglo XVII. Dicho proceso, como ha señalado Antonio Eiras Roel, se plasmaría en su progresiva institucionalización, evidenciada en aspectos tales como la convocatoria realizada a instancias del propio monarca y no por las propias ciudades como sucedía, la adopción de decisiones por mayoría de votos, el uso de un ritual protocolario hasta entonces inexistente, etc $^{32}$. Sin embargo, la causa real de la enajenación de la escribanía de las juntas, más que por el mero hecho en sí de otorgarle un reconocimiento legal, hay que buscarla en las penurias económicas de la propia monarquía en este momento. Así se desprende de la provisión real despachada por Felipe IV en Madrid el 24 de marzo de $1639^{33}$, concediendo a perpetuidad a Rodrigo Álvarez Becerra, escribano del número y ayuntamiento de A Coruña, la escribanía de las juntas como pago por la entrega de 500 ducados para las urgencias bélicas:

Y teniendo consideraçión a lo que vos Rodrigo Álbarez Beçerra, nuestro escrivano del número y ajuntamiento de la dicha çiudad, aveys servido algunos años el dicho oficio por nombramiento de los de la dicha Junta y, porque para las ocaçiones de guerra que de pressente se nos ofreçen aveys ofreçido serbirnos con quinientos

\footnotetext{
31 Antonio Eiras Roel (ed.), Actas de las Juntas..., vol. 3, pág. 26.

32 Véase "Las Juntas del Reino de Galicia en el período protoinstitucional, 1599-1629", en Antonio Eiras Roel (ed.), Actas de las Juntas..., vol. 1, págs. 44 y siguientes.

${ }^{33}$ Enrique Fernández-Villamil y Manuel de Artaza ofrecen fechas diferentes para esta concesión. Mientras que el primero la sitúa el 16 de marzo de 1639, el segundo la pospone hasta el año 1640. Véase Juntas del Reino de Galicia:..., vol. 2, pág. 59 y Rey, Reino y ..., pág. 157 respectivamente.
} 
ducados, pagados a ciertos plaços, de que abeis otorgado escritura de obligación ante Francisco de Yanguas, nuestro escrivano, ... ${ }^{34}$

Esta concesión incluía otra serie de prerrogativas tales como poder nombrar un sustituto por ausencia o enfermedad y cambiarlo, ceder o traspasar este oficio libremente a quien deseara, designar a otra persona que lo ejerciese mientras el futuro titular fuese menor de edad o muger soltera e incorporarlo a su propio mayorazgo, debiendo su heredero solicitar antes el título ${ }^{35}$. Ante este panorama, los diputados llamados a la Junta de enero-febrero de 1640 intentarían llegar a un acuerdo con Rodrigo Álvarez Becerra, ofreciéndose a comprarle el oficio por el mismo precio que en su día había abonado ${ }^{36}$. Lejos de ser una solución definitiva, la recuperación de la escribanía seguía todavía pendiente en 1643. Así en la conferencia del 13 de febrero de ese año, los representantes de las provincias acordaban de modo unánime no admitirle como escribano de las juntas ni de la diputación del Reino, ordenando que en lo sucesivo se informara de esto a los diputados futuros y que este acuerdo no se pudiese rebocar ${ }^{37}$.

A partir de esta última fecha, la recuperación de la escribanía por el Reino se iría complicando al estar pendiente el pago reclamado por Rodrigo Álvarez y al entrar de nuevo en escena Juan Becerra de Piñeiro. Sus primeros intentos de hacerse con la escribanía pueden rastrearse ya desde el año $1646^{38}$, pero no sería hasta el año siguiente cuando conseguiría que la Corona accediese a concedérsela mediante provisión real despachada en Madrid el 20 de mayo. En esta ocasión, la tesis esgrimida por Becerra de Piñeiro y que el propio monarca había aceptado, sostenía que el 12 de febrero de 1635 había sido nombrado escribano por el propio Reino a fin de paliar los perjuicios que suponía para el funcionamiento de la Junta de Reino el no tener un escribano fijo que guardase sus papeles e informase de las decisiones adoptadas en diferentes momentos. Y también ponía de relieve sus servicios a la Corona como escribano de guerra durante más de 28 años. Pero, al igual que en 1639, el factor determinante para decantar a su favor esta merced habían sido los 600 ducados entregados al erario real ${ }^{39}$. Pocos días después de dar comienzo la Junta de noviembre de 1648-febrero de 1649, Juan Becerra de Piñeiro hacía exhibición de su título, el 16 de noviembre de 1648, quedando encargado

\footnotetext{
${ }^{34}$ Antonio Eiras Roel (ed.), Actas de las Juntas..., vol. 4, pág. 324.

${ }^{35}$ Texto completo Ibidem vol. 4, págs. 323-326.

${ }^{36}$ Ibidem, pág. 138.

${ }^{37}$ Antonio Eiras Roel (ed.), Actas de las Juntas..., vol. 5, pág. 197.

${ }^{38}$ En el acta de la sesión del 14 de julio de 1646, correspondiente a la Junta celebrada en Pontevedra entre junio y julio de 1646, se le había denegado el uso de la escribanía del Reino. Antonio EirAs Roel (ed.), Actas de las Juntas..., vol. 5, pág. 401.

${ }^{39}$ Documento completo en Antonio Eiras Roel (ed.), Actas de las Juntas..., vol. 6, págs. 349-352.
} 
don Pedro Cid de Novoa, diputado de Ourense, de estudiar este asunto a fin de adoptar un dictamen. Este dictamen se retrasaría hasta el 25 de enero de 1649, cuando se le denegó el ejercicio del oficio y se le instó a su entrega inmediata, señalando la existencia de una disposición del monarca prohibiendo el uso de oficios añadidos y ordenando la recogida de los títulos ${ }^{40}$.

Pese a las súplicas de Rodrigo Álvarez y Juan Becerra para ser apoderados en la escribanía, el fracaso de esta tentativa dejaría como única salida la negociación para que les fuera devuelta la cantidad que habían gastado en su adquisición. Este cambio de rumbo es claramente perceptible desde 1656. Poco después de inaugurarse la Junta celebrada entre enero y abril de ese mismo año, se había recibido una carta de Francisco de Olazábal, agente del Reino, en la que avisaba haber conseguido una provisión del Consejo Real. Por esta provisión, solicitada en su día por el Reino, se les mandaba que remitiesen a dicho órgano los títulos de Rodrigo Álvarez y Juan Becerra a fin de determinar cuál de ellos tenía derecho a que se le comprase ${ }^{41}$. Sin que nos sea posible precisar los razonamientos esgrimidos -aunque pesaría de modo determinante el hecho de quién era el primer comprador-, el parecer del Consejo se decantaría a favor de Rodrigo Álvarez, a quien se extendía una carta ejecutoria a su favor. Una vez manifestado su contenido en la sesión del 18 de febrero de 1658, el responsable de trazar las líneas básicas del concierto entre Rodrigo Álvarez y el Reino sería don Antonio Alvite Ozores de Sotomayor, representante de Santiago de Compostela. Este concierto, ratificado por el resto de representantes, constaba de cuatro capítulos esenciales:

- la suma a abonar por el oficio de escribano se repartiría entre las siete capitales provinciales.

- para ello se solicitaría al monarca y al Consejo Real un despacho para hacer este reparto.

- Rodrigo Álvarez traspasaría al Reino los diplomas originales tras el pago correspondiente.

- y el rey se obligaría a no vender nunca más la escribanía ${ }^{42}$.

Pero pese a las buenas intenciones, la compra de la escribanía permanecería en suspenso durante varios años más, tal vez por no disponer de caudales con que afrontarla y por la resistencia del propio Becerra a entregar los títulos originales. De hecho, estas cuestiones parecen haber inspirado la oferta realizada en la Junta

\footnotetext{
40 Ibidem, págs. 104-105.

41 Antonio Eiras Roel (ed.), Actas de las Juntas..., vol. 7, pág. 128

42 Ibidem, págs. 282-283.
} 
de abril de 1664. Aparte de ratificar las líneas generales del pacto de 1658, se introducían dos nuevas cláusulas. Con ellas se pretendía salvaguardar el derecho del Reino a este oficio, obligando a Becerra a otorgar una escritura de cesión, y, si no accedía a ello, a dar garantías de la futura entrega de la suma pactada haciendo un depósito de la misma ${ }^{43}$. Este depósito con cargo al reparto de 785 reales y 25 maravedíes a cada capital provincial, quedaría en manos de don Pedro Sequeiros Sotomayor, quien los entregaría a Rodrigo Álvarez ${ }^{44}$.

Tras el fallecimiento de Rodrigo Álvarez Becerra, un sobrino suyo del mismo nombre conseguiría ver reconocidos sus derechos a la escribanía de las juntas en 1677. Si en un principio su reclamación había quedado en suspenso ${ }^{45}$, pocos días después, el 14 de septiembre de 1677, don Diego Félix Peralta y Velasco, Gobernador del Reino de Galicia, en conformidad al título y sobrecarta presentados por Rodrigo Álvarez Becerra el Mozo, le hacía entrega de la escribanía de las juntas $^{46}$. Aunque en el futuro el Reino intentaría entorpercer ${ }^{47}$ y hasta conseguiría paralizar $^{48}$ la posesión de Bernardo Álvarez Becerra, hijo y heredero de Rodrigo Álvarez Becerra el Mozo, a partir de 1703 la escribanía de las Juntas pasaría a ser ejercida por este personaje de modo casi ininterrumpido hasta 1746 y por sus sucesores, que optaron la mayoría de las veces por nombrar a un sustituto.

\section{Los requisitos exigidos}

Los requisitos exigidos a quienes ocupaban la escribanía de la Junta de Reino, no variaban sustancialmente de una modalidad a otra. Tanto si era el Reino, la ciudad "turnaria" o el escribano propietario quien los designaba, siempre recurrían a unos individuos con un perfil profesional bien definido. Del recuento realizado de las menciones que aparecen dispersas en los libros de actas, se deduce que existía una condición indispensable y otras dos que podemos calificar de secundarias o complementarias de la primera. Esta condición de la que hablamos radicaba en estar en posesión, por este orden, del título de escribano real, numerario, de concejo o todos ellos, repitiéndose esto en un $70 \%$ de las veces. Es más, si analizamos las ocasiones en las que el Reino nombra al escribano, observamos que el agraciado

\footnotetext{
43 Ibidem, págs. 334-335.

44 Ibidem, pág. 340.

${ }^{45}$ Durante la primera sesión de la Junta de septiembre de 1677-septiembre de 1678 el Gobernador del Reino había decidido ratificar a Pedro Rodríguez de Leis como escribano de la Junta y urgido a los diputados a que hiceran entrega de los 500 ducados del tanteo del oficio. Antonio EIRAs RoEL (ed.), Actas de las Juntas..., vol. 9, págs. 91-92

${ }^{46}$ Ibidem, pág. 94

${ }^{47}$ El 13 de mayo de 1697 la Junta de Reino había dirigido un memorial al Marqués de Astorga, Gobernador de Galicia, suplicándole que no admitiese a Bernardo Álvarez Becerra como escribano. Véase Antonio Eiras Roel (ed.), Actas de las Juntas..., vol. 11, págs. 582-583
} 
figura en primer lugar como escribano real en 7 ocasiones, uniendo a esto el ser escribano numerario y de concejo en 5 y 2 veces respectivamente. Esta preferencia por los escribanos reales también figura como un criterio inexcusable cuando las capitales provinciales asumen esta tarea desde la Junta de diciembre de 1649-julio de 1650. Como ya hemos señalado, los diputados habían acordado que el oficio recayese en los escribanos de sus ayuntamientos al juzgárseles como los más idóneos. Sin embargo, la renuncia de alguno de ellos a asumirlo ${ }^{49} \mathrm{y}$, sobretodo, el hecho de no ser escribanos reales ${ }^{50}$, les privaron de su ejercicio en 5 ocasiones.

Otras cualidades apreciadas a las que aludíamos, aunque no en la misma medida que la primera, resaltan la profesionalidad o el buen hacer de alguno de ellos al frente de la escribanía de la Junta, y que podía verse reforzada al haber actuado durante varios años consecutivos, lo que le confería un conocimiento muy cercano de la mecánica del oficio. Estas parecen ser las razones que llevaron al Reino a mantener a Jorge das Seixas casi de manera ininterrumpida desde la Junta de enero-febrero de 1640 a la de noviembre de 1648 -febrero de $1649^{51}$.

\section{Los sustitutos del escribano titular}

La responsabilidad de dotar de un sustituto que reemplazara al titular, recaía en la propia junta, previa propuesta del mismo titular ${ }^{52}$, o en el escribano propietario del oficio conforme a la facultad que su título le confería para ello. Fuera de un modo u otro, este sustituto quedaba desde ese preciso momento como depositario de toda la documentación que se hubiera generado o recepcionado hasta entonces,

\footnotetext{
${ }^{48}$ En las Juntas de junio-octubre de 1701 y marzo-mayo de 1702 el Gobernador había designado para atender la escribanía a Martín de Niebla, receptor de la Real Audiencia del Reino de Galicia, y a Antonio Fernández de Castro al estar pendiente el pleito con Bernardo Álvarez Becerra.

${ }^{49}$ El 1 de diciembre de 1649 el concejo compostelano había nombrado como escribano de la Junta de diciembre de 1649-julio de 1650 a Gregorio de Mandayo, escribano real, al excusar su asistencia Gregorio Pérez, escribano del concejo. Antonio Eiras Roel (ed.), Actas de las Juntas..., vol. 6, pág. 526.

${ }^{50}$ Esta situación se produjo en las Juntas de enero-abril de 1656, noviembre de 1656-febrero de 1657, enero-febrero de 1658 y abril de 1664.

${ }^{51}$ Al elegirle nuevamente para la Junta de noviembre de 1648 -febrero de 1649 , los diputados destacaban que "... a dado muy buena quenta de todos los negoçios de las Juntas del Reyno que asistió por eleçión suya y está en las materias muy notiçioso, en cuya consideraçión viendo que conbiene,..." Antonio Eiras Roel (ed.), Actas de las Juntas..., vol. 6, pág. 129.

52 "El dicho secretario Jorxe das Seixas dixo que la persona que en su lugar se aya de escusar en la secretaría de la Junta, que le a pareçido ser muy a propósito para ella, Diego Sánchez Somoça, receptor de primero número de la Real Audiencia y así suplica a Su Señoría, el Reino, le aga merced nonbrarle para ello, al qual dejará instruido en los despachos para la buena expedición dellos.

Que siendo visto por el Reino, de común conformidad nonbraron al dicho Diego Sánchez por escusador del dicho Jorje das Seixas durante su aussencia, al qual se le aga saber para que aga la jura." Actas, Antonio Eiras Roel (ed.), Actas de las Juntas..., vol. 5, pág. 251.
} 
entregándosela su predecesor ${ }^{53} \mathrm{o}$ teniendo que personarse en el inmueble donde esta se localizase ${ }^{54}$.

Esta dotación de una persona que le sustituyera temporalmente venía ocasionada por tres causas fundamentales. Como más adelante señalaremos, algunas comisiones que se encargaban al escribano oficial hacían que este tuviese que desplazarse a sitios alejados dentro del Reino de Galicia o en el resto de la Corona de Castilla ${ }^{55}$. Lógicamente la distancia y el tiempo que tardara en resolver las cuestiones planteadas, influirían directamente para que la intervención de dicho sustituto fuese más o menos prolongada. Los cálculos que hemos efectuado para Manuel Antonio Martínez en la Junta de marzo de 1709-enero de 1712, nos indican que se había limitado a 12 días, tiempo que Bernardo Álvarez Becerra habría invertido en viajar hacia A Coruña y Betanzos, practicar varias diligencias en ambas y retornar a Pontevedra ${ }^{56}$. Pero más que a esto, la no comparecencia se debía sobretodo a su enfermedad y a períodos de falta injustificada que podían superar el centenar de días ${ }^{57}$. Una vez expirado su tiempo de servicio y a fin de percibir la remuneración correspondiente, el sustituto debía justificar el tiempo de trabajo mediante la aportación de las certificaciones que lo acreditasen ${ }^{58}$.

\section{La duración y el cese en el oficio}

Durante buena parte del período que abarca este estudio, la permanencia de una persona al frente de la escribanía estaba supeditada a la duración de la junta para

\footnotetext{
${ }^{53}$ Así lo declaraba Bernardo Álvarez Becerra al nombrar en Pontevedra el 3 de junio de 1709 a Manuel Martínez. Antonio Eiras Roel (ed.), Actas de las Juntas..., vol. 14, págs. 721-722.

${ }^{54}$ Esta encomienda había forzado en mayo de 1708 a Francisco Antonio Vélez, sustituto de Bernardo Álvarez Becerra, a desplazarse a casa del contador don Julián Vicente Escudero en cuyas dependencias se había guardado todo lo relativo a la Junta de mayo de 1707-junio de 1708. Antonio EIRAS RoEL (ed.), Actas de las Juntas..., vol. 14, págs. 721-722.

${ }^{55}$ El 14 de mayo de 1644 Diego Sánchez Somoza, receptor del primer número de la Real Audiencia de Galicia, había reemplazado a Jorge das Seixas quien había partido rumbo a Madrid por orden del Reino. Antonio Eiras Roel (ed.), Actas de las Juntas..., vol. 5, pág. 247.

${ }^{56}$ El 3 de junio de 1709 Bernardo Álvarez Becerra había nombrado en Pontevedra a Manuel Martínez como escribano sustituto, el día 5 de junio de ese año ya se encontraba en A Coruña y habría vuelto a Pontevedra, a más tardar, el día 16 de ese mismo mes cuando vuelve a suscribir las actas de los acuerdos. Véase Antonio Eiras Roel (ed.), Actas de las Juntas..., vol. 14, págs. 721-722, 722 y siguientes.

57 Al final de la Junta de marzo de 1709-enero de 1712, el total de los días que Domingo de Ruibal, escribano de las rentas reales de la ciudad de Santiago, había servido la escribanía personalmente ascendían a 162 días. Cifra extraída de Antonio Eiras Roel (ed.), Actas de las Juntas..., vol. 15, págs. 279-280.

${ }^{58}$ Entre el 28 de mayo de 1705 y el 9 de junio del mismo año Francisco Antonio Vélez había despachado sucesivas certificaciones para justificar el tiempo durante el cual había estado reemplazando a Bernardo Álvarez Becerra. Antonio Eiras Roel (ed.), Actas de las Juntas..., vol. 13, págs. 398-404.
} 
la que se le nombraba. Tanto si era el Reino como cada capital provincial quien le designaba, una vez que la reunión llegaba a su fin, acababa el tiempo de servicio del escribano. Esta limitación, mencionada por primera vez en la Junta de febrero de $1626^{59}$, se completaría con otras dos que, por un lado, afirmaban la potestad del Reino a la hora de destituirle sin justificación alguna ${ }^{60} \mathrm{y}$ que, por otro, le impedían proseguir al frente de la misma sin su nombramiento ${ }^{61}$. Ello no fue impedimento para que un mismo individuo ocupara varias veces consecutivamente este oficio y, en un único caso, se le acabase nombrando de por vida. La explicación a esta aparente contradicción tiene que ver con determinados hábitos reiterativos a lo largo de las convocatorias que se fueron sucediendo. Un hecho perfectamente constatado es la clara predilección de A Coruña como sede de las juntas celebradas entre 1599 y 1834 . De las 113 reuniones que tenemos documentadas durante esos años, un $73 \%$ de las mismas tuvieron lugar en esta ciudad. Esto explica que, salvo contadas excepciones y estando vigente el modelo turnario, se recurriese por su proximidad a escribanos coruñeses que repiten varias veces al frente de la escribanía, siendo esto corriente en períodos como el que se extiende entre 1599 y $1641^{62}$. Esta repetición de una misma persona también solía darse si la junta se suspendía, quedando sin resolver el tema o temas centrales que habían dado lugar a su convocatoria. En esta situación, los diputados o las ciudades turnarias consideraban que el nombramiento proseguía en la siguiente y se limitaban a confirmarle ${ }^{63}$. Pero esta regla tampoco se mantendría indefinidamente ante el elevado coste económico que suponía para cada capital provincial el mantener al escribano durante más tiempo del esperado. Ello daría lugar a que en la Junta

\footnotetext{
${ }^{59}$ Cuando los diputados nombraban a Antonio de Cea Mariño, le advertían de que “... acabada la dicha Junta pueda nombrar el Reyno otro escribano todas las vezes que le pareçiere". Antonio EIRAS Roel (ed.), Actas de las Juntas..., vol. 1, pág. 355.

${ }^{60}$ Andrés de Fonseca Sampaio dejaba constancia en la Junta de diciembre de 1629 de que el Reino podría reemplazarle sin motivo aparente y designar a otro para ocupar su lugar. Antonio EIRAS RoEL (ed.), Actas de las Juntas..., vol. 1, págs. 434-435.

${ }^{61}$ El Reino advertía a los porteros y escribano designados para la Junta de enero-febrero de 1643 que no prosiguiesen al frente de estos oficios “... si no fuere por nonbramiento suyo". Antonio Eiras Roel (ed.), Actas de las Juntas..., vol. 5, pág. 176.

${ }^{62}$ De las 12 personas que ejercieron como escribanos entre la Junta de febrero-marzo de 1599 y la de julio de 1640-julio de 1641, Fernando de Gamarra y Antonio de Cea Mariño repitieron al frente del oficio en 9 ocasiones cada uno, Andrés de Fonseca Sampaio, en 7; Rodrigo Álvarez Becerra, en 4; Diego del Río, en 3; Jorge das Seixas, en 2 y Antonio García Salgado, Alonso Gondín, Diego de Vera, Francisco Pulleiro, Antonio Sobrino de Parga y Pedro Vázquez de Puga, en 1 sola.

${ }^{63}$ Entre los varios casos que se dan, citaremos a Antonio de Cea Mariño, nombrado para la Junta de mayo-agosto de 1636 y que prosigue en la de octubre-noviembre de ese mismo año. Lo mismo sucede con Juan Lorenzo y Aguiar, designado en uso de su turno por la ciudad de Lugo para la de enero-abril de 1656 y que continuaría en la de julio siguiente.
} 
de julio de 1656 se decidiese que cuando prosiguiese una junta, corriese el turno de nombrar al escribano ${ }^{64}$.

Menos frecuente era designar a alguien para que ocupara la escribanía vitaliciamente. Solamente en una ocasión los diputados optaron por ello al considerarse satisfechos con los servicios prestados por uno de estos profesionales de la escritura a lo largo de varios años. Esta merced recaería en Jorge das Seixas en la Junta de enero-febrero de 1643, manteniéndose como tal hasta la de noviembre de 1648-febrero de 1649, y de quien se destacaba al designarle su buen hacer y rectitud desde que había sido nombrado por primera vez en la de enero-febrero de $1640^{65}$.

Al margen de estas consideraciones, el establecimiento de la Diputación Permanente del Reino desde $1634^{66}$ para cuidar de los negocios y recepcionar la correspondencia cuando la junta no estaba reunida, favorecería que puntualmente el concurso del escribano se prolongara por más tiempo. Esta "detención”, si nos atenemos a lo declarado por Antonio de Cea Mariño, podía llegar a los seis meses que habían mediado entre la Junta de mayo-julio de 1635 y la de diciembre de 1635-enero de $1636^{67}$.

\section{Las Funciones del escribano de las Juntas del Reino de Galicia}

El trabajo del escribano de las Juntas del Reino de Galicia se desplegaba en un conjunto de tareas que guardaban una estrecha relación con el funcionamiento de esta institución. Si bien es cierto que se encuentran bien definidas casi desde un principio, estas tareas se verían acrecentadas con el paso de los años merced a factores tales como la complejidad de los asuntos debatidos, la mayor duración de las reuniones, el aumento del volumen de la documentación generada y las nuevas necesidades derivadas de su custodia y conservación o la observancia de un estricto protocolo a la hora de convocar a los diputados y rendirles los honores debidos. Estas funciones podemos agruparlas en cuatro parcelas diferentes.

\section{Fedatarias y notificativas}

El papel de fedatario constituía su cometido principal. Una vez recibido el aviso del señor Gobernador indicando la fecha exacta de la convocatoria de Junta de Reino, el escribano se personaba en la población designada para celebrarse. Antes

\footnotetext{
${ }^{64}$ Antonio Eiras Roel (ed.), Actas de las Juntas..., vol. 7, pág. 164.

65 Antonio Eiras Roel (ed.), Actas de las Juntas..., vol. 5, pág. 198.

${ }^{66}$ La propuesta y debate sobre la misma en Antonio EIRAs Roel (ed.), Actas de las Juntas..., vol. 2 , págs. 189-193 y breve reseña de la misma en pág. 902.

67 Antonio Eiras Roel (ed.), Actas de las Juntas..., vol. 2, págs. 372-373.
} 
de que se iniciara, su primera tarea consistía en expedir una fe de la llegada de cada diputado. Para ello acudía al señor Gobernador, quien le decía quiénes se habían presentado y quiénes aún no lo habían hecho o bien eran los propios interesados los que se la solicitaban directamente ${ }^{68}$. Tras dar comienzo a las sesiones, recibía los poderes de cada uno de los representantes, los revisaba a fin de comprobar que se ajustaban a los parámetros de la convocatoria $\mathrm{y}$, si se detectaba alguna falta o anomalía, informaba de ello en la primera o primeras asambleas. En este sentido, un conflicto recurrente en varias ocasiones vino originado por la presencia de la locución "cabeza de Reino" en la intitulación de los poderes expedidos por las ciudades de Santiago de Compostela y A Coruña. Este hecho suponía la ruptura del consenso alcanzado, por el cual ninguna de las capitales provinciales podía denominarse de tal manera, y motivaba la protesta airada del resto ${ }^{69}$. Para evitar en el futuro situaciones de este tipo que entorpeciesen el curso normal de la reunión, se le encargaba que buscara entre la documentación conservada las credenciales que en las juntas pasadas se había dado por ambas urbes a sus delegados. Una vez localizadas, extendía una certificación en la que hacía constar de forma resumida y concisa la fecha de la convocatoria, con qué finalidad, la identidad del amanuense ante quien se había otorgado dicha credencial y, lo más importante, si en ella aparecía la expresión objeto de polémica ${ }^{70}$. Esta primera toma de contacto con su trabajo remataba al transmitir a las autoridades locales el nombre de los oficiales que asistirían al Reino a fin de que no se entorpeciese el ejercicio de sus facultades y al pasar aviso a alguno de estos oficiales, como los porteros, del horario de las reuniones para que se personasen bajo la promesa de que "... se les dará sattisfaçión de su trabajo según costumbre”.

Una vez solucionados estos pormenores, la misión esencial del escribano era levantar acta de los acuerdos alcanzados durante las deliberaciones, dejando constancia en todas ellas de qué diputados estaban presentes y de la asistencia de ciertos personajes y la cortesía que se les había dispensado ${ }^{71}$. Dado que algunas veces los debates se prolongaban varias jornadas sin llegar a ningún consenso, estaba obligado por lo menos a indicar cuál o cuáles eran los temas sobre los que

\footnotetext{
${ }^{68}$ Un día después de llegar a A Coruña, el 10 de noviembre de 1692, don Manuel Canel de Fresnedo, diputado de Mondoñedo, se había personado ante el escribano de las Juntas para solicitarle una certificación. Antonio Eiras Roel (ed.), Actas de las Juntas..., vol. 11, pág. 471.

${ }^{69}$ Sobre este tema, remitimos al lector al ya citado Enrique Fernández-Villamil Alegre, Juntas del Reino de Galicia:..., vol. 2, págs. 219-226

${ }^{70}$ Un suceso de este cariz tuvo lugar en la Junta de junio-octubre de 1701. Narración en Antonio Eiras Roel (ed.), Actas de las Juntas..., vol. 12, págs. 130-138. Certificación expedida por Martín de Niebla en Ibidem, págs. 553-560.

${ }^{71}$ Véase el acuerdo del 9 de octubre de 1621 por el que se decide dejar constancia de la presencia de don Rodrigo Pacheco, Gobernador del Reino, y de don Luis de Villagutierre, alcalde mayor, a la sesión del día anterior. Antonio Eiras Roel (ed.), Actas de las Juntas..., vol. 1, págs. 240-241.
} 
discutía. Así entre el 20 y 29 de septiembre de 1682, Pedro Sánchez Delgado, excusador de Rodrigo Álvarez Becerra, había dejado constancia de que la labor de los diputados a lo largo de estos nueve días se había limitado a estudiar la documentación referente al impuesto de la sisa, empleando para no repetir lo mismo la expresión "... para el effecto que mencionan los acuerdos antecedentes ..."’2. No sucedía lo mismo cuando se suspendía cautelarmente cualquier decisión ante la falta de algunos requisitos legales, pues si bien los miembros congregados proseguían debatiendo, se señalaba que se trataba exclusivamente de “... conferencias vervales ...”, es decir, no se ponían por escrito ${ }^{73}$. Además de las actas, el escribano redactaba, enviaba y notificaba todos los documentos que se le encargasen y avisaba de los que recibía. De este modo, sacaba copia de la real cédula convocatoria, que figuraba, sobretodo desde el siglo XVIII, como cabecera del libro de la junta, y de otros diplomas en los que se le dictaban instrucciones para su expedición y conservación ${ }^{74} \mathrm{o}$ buena caligrafía ${ }^{75}$. Estas recomenciones se extendían a las mismas cláusulas documentales cuando se abordaban negocios que por su transcendencia suponían para el Reino una fuerte inversión de capital. Por ello, y antes de la redacción definitiva, debía presentar un borrador o leerlo a los diputados por si querían añadir algo más ${ }^{76}$, o al Gobernador para que hiciese las consideraciones pertinentes ${ }^{77}$. Igualmente extendía diversas certificaciones que se le pedían, o bien para demostrar el cumplimiento de algunos encargos que

\footnotetext{
72 Antonio Eiras Roel (ed.), Actas de las Juntas..., vol. 10, págs. 108-113.

${ }^{73}$ Como consecuencia de la anulación de los poderes de los diputados de Santiago de Compostela y A Coruña en la Junta de junio-octubre de 1701, se había suspendido la transacción de las cuentas de los tanteos de rentas y millones hasta que ambas ciudades remitiesen nuevos poderes. Mientras tanto los diputados siguieron debatiendo, pero sin tomar ninguna decisión. Antonio EirAs Roel (ed.), Actas de las Juntas..., vol. 12, pág. 110 y siguientes.

${ }^{74}$ En la Junta de febrero-marzo de 1599 al designar el Reino a los procuradores que acudirían a la Corte para solicitar del monarca la recuperación del voto en Cortes del Reino de Galicia, se había ordenado al escribano que les hiciese entrega de los poderes originales de los cuales quedase un traslado en el legajo correspondiente. Antonio Eiras Roel (ed.), Actas de las Juntas..., vol. 1, págs. 176-177.

${ }^{75} \mathrm{Al}$ disponer en diciembre de 1638 la encuadernación de los originales de la real cédula concediendo el voto en Cortes al Reino de Galicia, el asiento realizado con el monarca para la construcción de una escuadra y los asientos para ello, entre otros, se había ordenado a Diego del Río que si algunos originales no tenían buena letra, sacase un traslado de los mismos. Antonio Eiras Roel (ed.), Actas de las Juntas..., vol. 3, págs. 349-350.

${ }^{76}$ Con motivo de la suscripción del contrato con Francisco de Quincoces para el abastecimiento de la escuadra gallega, se había presentado un borrador de dicho contrato en la sesión 11 de enero de 1636 a fin de que los representantes de las provincias hiciesen sus aportaciones. Texto en Antonio Eiras Roel (ed.), Actas de las Juntas..., vol. 2, pág. 354.

${ }^{77}$ Antes de hacer efectivo en 1705 el acuerdo con don Domingo de la Fuente, tesorero del arbitrio impuesto para la equipación de ocho tercios con los que el Reino debía servir a la Corona, los diputados decidieron que el escribano pasara a dar cuenta del mismo al Gobernador. Antonio EirAs Roel (ed.), Actas de las Juntas..., vol. 13, pág. 231.
} 
se le hacían ${ }^{78}$. Cuando por razones extraordinarias algún diputado se ausentaba varios días, el escribano pasaba a notificarle personalmente cualquier asunto que requiriese su asenso ${ }^{79}$. A juzgar por los numerosos datos que hemos recopilado, estas actividades ocupaban la mayor parte del tiempo de su trabajo y le obligaban a salir de la localidad donde se desarrollaba la junta. Estas salidas tenían como objetivo la búsqueda y localización de determinada documentación que se deseaba consultar $^{80}$ y la realización de algunas diligencias por orden del Reino ${ }^{81}$.

Cuando la reunión se acercaba ya a su remate, el escribano se apresuraba a sacar siete copias compulsadas del libro original de la junta. Una vez confeccionadas, se entregaban a cada uno de los diputados, quienes debían remitirlas a sus respectivas ciudades para que sirviesen como prueba de todo lo tratado ${ }^{82}$. Pero tanto el diseño del original como la elaboración de sus reproducciones no siempre se realizaban con la rapidez y precisión deseadas y, en consecuencia, su formato definitivo podía verse alterado. Este defecto hay que achacarlo tanto a la extracción de ciertos documentos cuando ya estaban encuadernados ${ }^{83}$ como a su ausencia en algunos de los manuscritos. Esta carencia venía motivada por el retraso en la entrega de determinados diplomas. Si esto acontecía, el escribano debía adjuntarlos a la junta original y remitir un traslado de cada uno de ellos a aquellas ciudades que se lo solicitasen, aun cuando ya tuviesen en su poder la

\footnotetext{
${ }^{78}$ Uno de los numerosos ejemplos lo hallamos en la Junta celebrada en Pontevedra entre mayo de 1707-junio de 1708, cuando Bernardo Álvarez Becerra había expedido una certificación señalando que el 18 de febrero de 1708 había entregado a Nicolás Pérez, correo de a caballo, un pliego dirigido a don José Grimaldo, Secretario del Despacho Universal. Antonio Eiras Roel (ed.), Actas de las Juntas..., vol. 14, pág. 409.

${ }^{79}$ Dada la indisposición por enfermedad de don Francisco Antonio Saavedra, diputado de Mondoñedo, se había acordado en la reunión del 1 de abril de 1716 que el escribano pasara a informarle de los asuntos abordados. Miguel Romaní Martínez (ed.), Xuntas do Reino de Galicia: actas, vol. 16, Santiago de Compostela, Dirección Xeral de Patrimonio Cultural, pág. 119.

${ }^{80}$ El 28 de enero de 1641 se habían dictado unas instrucciones muy precisas a Jorge das Seixas, escribano de la Junta de julio de 1640-julio de 1641, a fin de que buscara en A Coruña ciertos diplomas de juntas anteriores y los trajese a Tui e insistiéndosele en que despachase este cometido con rapidez. Antonio EIras Roel (ed.), Actas de las Juntas..., vol. 4, págs. 521-522.

${ }^{81}$ El 2 de junio de 1711 Bernardo Álvarez Becerra había partido de Pontevedra rumbo a Tui a fin de notificar a don Domingo de la Fuente, juez ordinario de dicha ciudad, la necesidad de reunirse su consistorio para elegir a un nuevo diputado al estar suspendido por el Reino el anteriormente nombrado. Relato completo en Antonio Eiras Roel (ed.), Actas de las Juntas..., vol. 15, págs. 554-570.

${ }^{82}$ La decisión de sacar estas copias del original se había adoptado por primera vez durante la Junta de julio de 1640-julio de 1641 en la sesión del 8 de julio de 1641. Antonio Eiras Roel (ed.), Actas de las Juntas..., vol. 4, pág. 304.

${ }^{83}$ Bernardo Álvarez Becerra informaba el 8 de junio de 1711 que había extraído del libro de juntas varios diplomas adjuntos a las conferencias de los día 1 y 6 de junio por orden del Gobernador a fin de reunir toda la información necesaria sobre el nombramiento de Domingo de la Fuente como diputado por la ciudad de Tui. Antonio Eiras Roel (ed.), Actas de las Juntas..., vol. 15, pág. 575.
} 
copia correspondiente ${ }^{84}$. Estos y otros imprevistos unidos a la propia laboriosidad de transcribir íntegramente cada ejemplar, obligaban al escribano a proseguir su tarea después de finalizada la junta. En previsión de esto, el Reino solía concederle entre 6 y 8 días y una suma adicional para pagar a los oficiales que le ayudaban, como expresaba Pedro Sánchez Delgado al hacer balance de sus días de servicio en la Junta de noviembre de 1692-mayo de 1693:

asistió a dar fee de la Junta que aora últimamente se çelebró, diçe que los caballeros diputados della le consideraron quinçe dias de salario, que lexítimamente ocupó, siendo estilo, usso y costumbre que al tiempo que se haçe el rateo de los gastos se le considera más seis u ocho días para sacar las copias de la Junta que cada diputado lleba a su çiudad, y çien reales para ayuda de los escribientes ${ }^{85}$.

\section{Hacendísticas}

Otro de los campos de actuación del escribano era el hacendístico. Sin embargo, conviene precisar que sus atribuciones en materia económica, ya sea por la parquedad de las fuentes documentales o bien porque sus competencias no se extendían a este ámbito, no aparecen claramente definidas hasta la tercera década del siglo XVII. Dicha novedad, si podemos llamarla así, se produjo por primera vez cuando antes de clausurarse la Junta de abril-mayo de 1634, los diputados acordaron que el escribano llevase control de todo lo gastado durante la misma ${ }^{86}$. Aunque el monto principal de dichos gastos solía desembolsarse a la finalización de la junta con cargo al reparto realizado entre las siete provincias ${ }^{87}$, otras cantidades de menor cuantía y derivadas de la actividad burocrática cotidiana, tales como el transporte de enseres como las mazas y ropas de los maceros y de la escribanía de la Junta, la compra de papel sellado y común, los derechos de expedición documental, los portes de la correspondencia o el auxilio de uno o más oficiales, corrían muchas veces por su cuenta y se le pagaban al final. Una evidencia de lo que acabamos de enumerar, lo localizamos en el memorial

\footnotetext{
${ }^{84}$ El 6 de julio de 1693 el escribano Pedro Sánchez Delgado y Fandiño informaba de la entrega de un memorial, decreto y carta por parte del regidor coruñés don Francisco de Puzo y Aguiar correspondientes a la Junta que se había desarrollado entre noviembre de 1692 y mayo de 1693 . Antonio Eiras Roel (ed.), Actas de las Juntas..., vol. 11, pág. 580.

${ }^{85}$ Antonio Eiras Roel (ed.), Actas de las Juntas ..., vol. 11, págs. 596-597.

${ }^{86}$ Antonio Eiras Roel (ed.), Actas de las Juntas..., vol. 2, pág. 205.

${ }^{87}$ Una amplia relación de estos gastos recogida en Enrique Fernández-Villamil Alegre, Juntas del Reino de Galicia:..., vol. 2, págs. 142-176. Nuevas aportaciones en Laura Fernández VegA, "Orígenes y antecedentes,...", pág. 71 y siguientes.
} 
presentado por Jorge das Seixas a finales de febrero de 1640, correspondiente al dinero que había desembolsado en la Junta de enero-febrero de ese año y que solicitaba que se le satisfaciese.

Tabla 1: Sumas adeudadas a Jorge das Seixas al finalizar la Junta de Reino de enero-febrero de 1640

\begin{tabular}{|l|c|c|}
\hline Concepto & Sumas (en reales) & Porcentaje \\
\hline Papel y derechos & 154,47 & $22,05 \%$ \\
\hline Pago a marineros & 33,82 & $4,80 \%$ \\
\hline Portes de cartas & 2,00 & $0,28 \%$ \\
\hline Traslados de juntas & 494,11 & $70,50 \%$ \\
\hline Pago a un oficial & 16,00 & $2,28 \%$ \\
\hline Total & 700,41 & \\
\hline
\end{tabular}

Fuente: Antonio Eiras Roel (ed.), Actas de las Juntas..., vol. 4, págs. 438-439.

Al tocar la junta a su fin y a requerimiento del Gobernador, el escribano elaboraba el rateo de todo lo consumido, especificando en cada partida el concepto o conceptos adeudados, la identidad del demandante y la cuantía adeudada. Especial cuidado era el que ponía en todo lo tocante a los jornales y dietas de los diputados y resto de oficiales, a fin de que se ajustasen con exactitud al tiempo que ambos grupos habían permanecido en servicio e indicando, en caso de salida, la causa y la duración de la misma. Para ello recurría a las certificaciones de la fecha de llegada y partida de la ciudad que tenía de cada uno de ellos o bien las solicitaba a los propios interesados. Tras pasar la pertinente revisión del Gobernador y si no había ningún imprevisto ${ }^{88}$, el escribano remitía a cada ciudad las partidas asignadas en dicho reparto y, en caso de que se retrasasen en abonarlas, les exigía por medio de sus diputados el reingreso de las mismas ${ }^{89}$. Este papel

\footnotetext{
${ }^{88} \mathrm{Al}$ estar pendiente una resolución de la Corona, el escribano Bernardo Álvarez Becerra había dejado en suspenso el rateo de la Junta de julio de 1703-enero de 1704 que había comenzado el 24 de enero de 1704 hasta el día 28 del mismo mes y año. Antonio Eiras Roel (ed.), Actas de las Juntas..., vol. 12, págs. 367-368 y 699-700.

${ }^{89}$ El 28 de mayo de 1690 Pedro Sánchez Delgado y Fariña, escribano en la Junta de abril de 1690, dirigía una carta a don Álvaro de Castro y Neira, diputado de Lugo, solicitándole la entrega de 534,5 reales que correspondían a su ciudad en el reparto hecho para el pago a los oficiales quienes ya habían recurrido al Gobernador al creer que dicha cantidad ya estaba en su poder. Antonio EIRAs Roel (ed.), Actas de las Juntas..., vol. 11, pág. 416,
} 
preponderante en el control de la contabilidad queda patente en el hecho de que siempre le correpondía, en último extremo, subsanar cualquier error que pudiese detectarse si el Gobernador solicitaba el rateo a los mismos diputados ${ }^{90}$.

\section{Custodio de la documentación y enseres de la Junta de Reino}

Una de las preocupaciones fundamentales de la Junta de Reino casi desde sus comienzos era la preservación de la documentación generada y recibida durante sus reuniones junto con el resto de enseres empleados, entre otros, el sello del Reino, el tintero, la salvadera, la campanilla de plata y una sobremesa de terciopelo verde ${ }^{91}$. La confección y el manejo de los documentos por parte del escribano, hacía que la mayoría de las veces estuviesen en su poder. Esta tónica resulta habitual en el primer cuarto del siglo XVII, pues si alguno o algunos de los asistentes deseaba consultar libros de juntas u otros diplomas pasados, debía solicitárselo a él directamente ${ }^{92}$. Con todo, algunos indicios aparecidos en determinadas sesiones nos inducen a apuntar a otras posibles razones. Una de ellas procedía de la dinámica con la que se desesenvolvían las jornadas de trabajo en la junta. Cuando los diputados, ya por estar ocupados o juzgar mejor debatirlo más adelante, decidían posponer la resolución sobre un tema concreto, entregaban todo el papeleo correspondiente al escribano, encargándole que lo trajese cuando se abordara ${ }^{93}$. En otras circunstancias, propiciadas por el relevo en la escribanía o al regir el nombramiento por turnos entre las ciudades y la obligación de que todos los papeles estuviesen en unas mismas manos, se ordenaba su entrega al nuevo amanuense, quien, como prueba de su recepción, extendía un recibo a su antecesor ${ }^{94}$.

\footnotetext{
${ }_{90}$ Tras examinar el rateo entregado por los diputados de la Junta de julio-diciembre de 1691, el Gobernador había ordenado al escribano Pedro Sánchez Delgado y Fariña que elaborase uno nuevo en el que se incluyesen las anotaciones que de su puño y letra hacía en los márgenes. Antonio EirAs Roel (ed.), Actas de las Juntas..., vol. 11, pág. 467.

${ }^{91}$ La fabricación de este instrumental se había encargado por primera vez en la última sesión de la Junta de junio-julio de 1625 celebrada el 4 de julio. Antonio Eiras Roel (ed.), Actas de las Juntas..., vol. 1, pág. 314.

${ }^{92}$ En la tercera conferencia celebrada el 8 de diciembre de 1613 , los diputados “... dixeron y acordaron y mandaron que mañana lunes, yo, escrivano destas Juntas, traiga al ayuntamiento y Junta que se a de açer, las juntas pasadas para que se ben y lean y sean informados y enterados de las cosas que en ellas se an tratado..." Antonio Eiras Roel (ed.), Actas de las Juntas..., vol. 1, pág. 200.

${ }_{93}$ Al recibirse tres cartas recomendando a don Benito Abraldes Fajardo para capitán de una de las compañías que había de servir en la esquadra del Reino, los diputados las entregaron al escribano para que las trajese a la sesión en la que se tratase dicho nombramiento. Antonio Eiras Roel (ed.), Actas de las Juntas..., vol. 1, pág. 395.

${ }^{94}$ A propuesta de don Antonio de Luna, diputado de Betanzos, el Reino había acordado solicitar a don Antonio de Cea Mariño, escribano, ante quien pasara la Junta de junio-julio de 1625 su entrega a don Fernando de Gamarra quien asistía al Reino en la de octubre de 1625 y se ofrecía, si así se lo pedía, a extenderle un justificante de ello. Antonio Eiras Roel (ed.), Actas de las Juntas..., vol. 1, pág. 322.
} 
Este "monopolio" ejercido por el escribano en la custodia de la documentación y de los mismos enseres mudaría sensiblemente a partir de la Junta de junio-julio de 1625. Esta mutación obedecía al deseo de disponer de un mueble de fácil manejo y en el que guardar todos los originales y otros papeles. Dicho mueble, consistente en un cajón portátil cuya fabricación se encomendaba a don Bernardino Yáñez Prego, representante de Santiago de Compostela, estaría dotado de tres llaves, una de las cuales se entregaría al escribano cuando se le nombrase y las otras dos estarían en poder de las ciudades que en ese momento gozasen del voto en Cortes ${ }^{95}$. Esta restricción en el libre acceso a los diplomas y resto de útiles no sería un óbice para que el escribano siguiese ocupando un rol central y preponderante en su gestión, en especial en todo aquello que tenía que ver con su transporte, guarda en determinados momentos y salvaguarda en buen estado. Así cuando el Gobernador le avisaba de la fecha y lugar en el que se inauguraría la junta, o bien si una vez comenzada ésta decidía mudar de población, también le ordenaba que trajese toda la documentación y utensilios necesarios. En situaciones excepcionales como podía ser la falta de mobiliario adecuado, se le encargaba que los retuviese en su poder hasta que éste se fabricase ${ }^{96}$.

Otra ocupación que los diputados del Reino fueron descargando en manos del escribano, pese al compromiso adquirido de hacerlo ellos mismos ${ }^{97}$, sería la clasificación, ordenación, descripción y preservación de la documentación. Todas estas operaciones tenían que ver con el gran caudal documental acumulado, el desorden en el que muchas veces se hallaba y, relacionado con lo anterior, el perjuicio que ello suponía para la operatividad de la propia institución. Esta situación era la que los diputados describían en la Junta de septiembre-octubre de 1682 al constatar que los libros carecían de encuadernación y sus folios no estaban pautados ni numerados, lo cual entrañaba no pocas dificultades para localizar determinados capítulos que se deseaban consultar ${ }^{98}$.

\footnotetext{
95 Antonio Eiras Roel (ed.), Actas de las Juntas..., vol. 1, pág. 314.

${ }^{96}$ Durante la última sesión de la Junta de marzo de 1651, celebrada el día 29 de dicho mes y año, los diputados habían acordado que Gregorio de Mandayo conservara en su poder los papeles de las juntas junto con el tintero, salvadera, caja de oblea, campanilla de plata, mazas y ropas de los maceros mientras se fabricaba una nueva arca. Antonio Eiras Roel (ed.), Actas de las Juntas..., vol. 6, pág. 288.

${ }^{97}$ El 2 de diciembre de 1638 los diputados habían vuelto a reiterar un acuerdo alcanzado con anterioridad referente a la obligación de encuadernar ellos mismos los papeles del Reino. Antonio EIRAS Roel (ed.), Actas de las Juntas..., vol. 3, págs. 349-350.

98 Antonio Eiras Roel (ed.), Actas de las Juntas..., vol. 10, pág. 114.
} 


\section{Enlace con el Gobernador}

La comunicación entre los diputados y el Gobernador no siempre se establecía de modo directo, sino a través de unos cauces preestablecidos. Esta particularidad se ponía de manifiesto desde la misma apertura oficial de la junta que se desenvolvía siguiendo un ritual protocolario perfectamente diseñado en cada una de sus manifestaciones ${ }^{99}$.

Antes de dar comienzo a las sesiones y como requisito indispensable, el escribano se personaba ante el Gobernador con el objeto de obtener el permiso necesario para que los representantes de las provincias acudiesen a su presencia. Una vez retornado al lugar donde le aguardaban, les comunicaba el día y hora para la recepción oficial. Llegado ese día, integraba el séquito formado por los siete diputados, dos porteros, otros dos maceros, el alguacil mayor y resto de autoridades civiles y militares que salía en procesión hasta la entrada de la residencia oficial. Allí eran recibidos por el representante de la Corona, quien saludaba y conducía a los diputados y al escribano a la sala del Real Acuerdo. Ya en su interior y tras tomar asiento, el mismo escribano recibía de manos del Gobernardor la real cédula convocatoria, que leía a fin de revelar la temática de la misma y, a mayores, ofreciendo otros detalles tales como sus caracteres externos y la identidad de sus suscriptores ${ }^{100}$.

Este papel de interlocutor se hacía extensible a la recepción o transmisión de algunos documentos. Dada su posición como delegado regio, el Gobernador solía ser a quien la Corona hacía llegar su determinación sobre ciertos temas planteados por la junta y a quien los diputados acudían cuando precisaban hacer efectiva alguna orden dirigida a las capitales provinciales. Fuera una u otra, el escribano pasaba a solicitársela, traspasársela o a recibir las instrucciones precisas para su entrega personal al Reino ${ }^{101}$.

\footnotetext{
${ }_{99}$ El ceremonial practicado aparece ampliamente descrito en Enrique Fernández-VILLAmil AlEgRE, Juntas del Reino de Galicia:..., vol. 2, págs. 94-113.

100 " $Y$ dicho señor Governador me dio abierta otra carta, escripta en molde, del Reino junto en Cortes, para heste Reino, que yo, scrivano, ansimismo ley, que benía firmada de Rafael Cornejo y Juan de Palma, scrivanos mayores." Antonio Eiras Roel (ed.), Actas de las Juntas..., vol. 2, pág. 111. ${ }^{101}$ El 23 de diciembre de 1635 el Marqués de Mancera, Gobernador del Reino, se había negado a entregar un pliego dirigido al Reino por su Magestad, argumentando que "...hera neszesario entregárselo de su mano al Reino. Y así, que a las tres oras del medio día se serbiese el Reino de juntarse en su cassa, en la Sala del Acuerdo, donde suele juntarse quando hes neszesario hazer alguna nueba propusisión con Su Excelencia, e..."Antonio Eiras Roel (ed.), Actas de las Juntas..., vol. 2, pág. 341.
} 


\section{LA REMUNERACIÓN DEL ESCRIBANO DE LAS JUNTAS}

Dentro de los gastos causados por la Junta ${ }^{102}$, figuraba en un mismo apartado junto a las dietas de los diputados la suma abonada al escribano por sus servicios. En los años que median entre las juntas de febrero-marzo de 1599 y mayo-agosto de 1636, este oficial no contaba con una asignación fija, sino que ésta solía calcularse, como para el resto de dependientes, en base a una tasación. Este sueldo sería fijado por primera vez en 11,76 reales diarios en la Junta de octubre-noviembre de $1636^{103}$ y permanecería inalterable, salvo mínimas variaciones ${ }^{104}$, hasta la Junta de noviembre de 1638 -febrero de 1639 cuando al confirmar el nombramiento de Diego del Río se le asignaban 17,64 reales ${ }^{105}$. Posteriormente se incrementaría en 23,52 reales en la Junta de febrero-marzo de $1642^{106}$ para en la de marzo-mayo de 1644 pasar a 29,41 reales ${ }^{107}$. Este sueldo experimentaría en años venideros sensibles oscilaciones tanto a la alza como a la baja. Una primera subida tuvo lugar en la junta de abril-mayo de 1681 en la cual Rodrigo Álvarez Becerra se habría embolsado 8.448 reales por su trabajo durante 192 días a 44 reales por día ${ }^{108}$, cantidad esta que a la postre se convertiría en la que habitualmente se abonaba ${ }^{109}$. Pero el "máximo histórico" en lo que a jornal se refiere, se alcanzaría en la de noviembre de 1739-enero de 1740 con los 51 reales que se ratearon a Bernardo Álvarez Becerra ${ }^{110}$. Al lado de estos incrementos, también hemos hallado tres descensos significativos en sus percepciones económicas. El primero, en la Junta de junio-octubre de 1701, vino propiciado por el hecho de que el amanuense, llamado Martín de Niebla,

\footnotetext{
${ }^{102}$ Una aproximación a los mismos en Laura Fernández Vega, "Orígenes y antecedentes, ...”, pág. 71. Relación más detallada en Enrique Fernández-Villamil Alegre, Juntas del Reino de Galicia:..., vol. 2, pág. 144 y siguientes.

103 "En esta Junta se acordó que por quanto los escrivanos y porteros que suelen ser desta Junta no tienen salario fixo, y sienpre sirven con esperanza, pareze conveniente que de aqui adelante le tengan para que se sepa el premio que an de tener y mereszen, desde luego se les señala al escrivano de aqui adelante quatrocientos maravedís con escriptura y todo lo demás, y a los porteros a zien maravedís cada uno." Antonio EiRas Roel (ed.), Actas de las Juntas..., vol. 3, págs. 122-123

${ }^{104}$ En la Junta de septiembre-diciembre de 1637 Rodrigo Álvarez Becerra había recibido 38.000 maravedíes por 86 días de servicio, lo que equivalía a 441 maravedíes diarios.

${ }^{105}$ Antonio Eiras Roel (ed.), Actas de las Juntas..., vol. 3, pág. 345.

${ }^{106}$ En la última sesión celebrada el 27 de marzo de 1642, se había encargado a Juan Martínez de Saavedra y a Alonso de Lara, diputados de las ciudades de Mondoñedo y Tui respectivamente, que revisaran el total de lo adeudado a Jorge das Seixas a razón de 800 maravedíes por día. Antonio Eiras Roel (ed.), Actas de las Juntas..., vol. 5, pág. 126.

${ }^{107}$ Ibidem, pág. 252.

${ }^{108}$ Antonio Eiras Roel (ed.), Actas de las Juntas..., vol. 10, pág. 95.

${ }^{109}$ Los cálculos realizados para las 57 reuniones de las que tenemos información, indican que en el $52 \%$ de las ocasiones el escribano había recibido esta cuantía.

${ }^{110}$ Miguel Romaní Martínez (ed.), Xuntas do Reino..., vol. 18, pág. 177.
} 
pertenecía al cuerpo de los receptores de la Real Audiencia de Galicia cuyos honorarios estaban estipulados en 15 reales, a lo que se añadía el no haber tenido que salir de A Coruña donde vivía ${ }^{111}$. Atendiendo a este precedente, los diputados habían decidido conceder la misma cantidad a Antonio Fernández de Parga al comenzar la Junta de marzo-mayo de $1702^{112}$. Uno de estos factores, la no estancia fuera de su hogar, puede ser la clave para entender que a Bernardo Álvarez Becerra solamente se le asignasen 17 reales diarios en la junta de febrero-abril de 1716, ya que en las anteriores se había desplazado a Pontevedra ${ }^{113}$ o había rotado entre esta ciudad y otras dos ${ }^{114}$.

Este salario manejaba dos variantes como eran el tiempo durante el cual había permanecido al servicio del Reino y el importe de los materiales consumidos durante el mismo. El primero de ellos, el tiempo de servicio al Reino, se contabilizaba tomando como fecha límite inicial aquélla en la cual se hubiese personado en la sede de la reunión, la de la notificación para que compareciese o, si acudía desde otro lugar, la de partida de su casa. Si su casa se hallaba a una distancia considerable y si se le había encomendado algún encargo de camino, el escribano de la junta acostumbraba a partir con varios días de antelación, notificando su llegada y mostrando los justificantes en los que constara el día y la localidad de la que había salido y la ruta seguida. Así, por ejemplo, el 15 de diciembre de $1656^{115}$, tres días después de ser nombrado por el consistorio lucense para la Junta de enero-abril de 1656, Juan Lorenzo y Aguiar había salido rumbo a Betanzos donde el día 17 de este mes se había detenido a recoger toda la documentación y enseres de manos de su antecesor ${ }^{116}$. Desde allí se había dirigido a Pontevedra, sede de la reunión, a donde había arribado el 21 de diciembre ${ }^{117}$. Esta prisa por llegar a su destino días e incluso semanas antes de que oficialmente se abriesen las sesiones parlamentarias, no debe vincularse al interés que pudiese tener por la percepción de unos mayores honorarios, sino que hay que encuadrarla, como hemos visto al tratar de sus funciones, dentro de la preparación de todos los medios materiales para que éstas, las sesiones, se desarrollaran con la formalidad

\footnotetext{
${ }^{111}$ Antonio Eiras Roel (ed.), Actas de las Juntas..., vol. 12, pág. 240.

112 " $Y$ ansimismo me doy por contento con la paga de dos ducados al día, que los señores diputados en nonbre del Reino me señalan, según y como se señaló y pagó a Martín de Niebla". Antonio Eiras Roel (ed.), Actas de las Juntas..., vol. 13, pág. 619.

${ }^{113}$ Así sucedió en las juntas de octubre-diciembre de 1704, febrero-agosto de 1705, mayo de 1707-junio de 1708 y septiembre-octubre de 1712 .

${ }^{114}$ La junta de marzo de 1709-enero de 1712 había comenzado en A Coruña y proseguido en Santiago de Compostela y Pontevedra, interrumpiéndose varias veces a lo largo de esos años.

${ }^{115}$ Antonio Eiras Roel (ed.), Actas de las Juntas ..., vol. 7, págs. 551-552.

${ }^{116}$ Ibidem, págs. 553-554.

${ }^{117} \mathrm{Ibidem}$, pág. 555
} 
acostumbrada $^{118}$. Al llegar casi a su término y calculado el rateo de los gastos, se le concedían entre 2 y 8 días más que se estimaban necesarios para extender las copias, despachar algunos papeles y retirarse a su residencia. Fuera de esta consideración de días "hábiles" quedaban aquellos otros en los que la junta se hubiese suspendido momentáneaneamente o en los que hubiese causado baja por convalecencia o ausencia voluntaria ${ }^{119}$. Otra suma devengada, como se ha indicado más arriba, estaba compuesta por los materiales consumidos, es decir, el coste del papel sellado y común empleado en la redacción del libro de actas, sus copias y otros documentos; los traslados de algunos de ellos, la oblea para el sellado, los portes de envío de la correspondencia o la cera consumida en la iluminación. En comparación con el salario, y siempre y cuando ambos no aparecen fusionados, su importe suponía una cuantía mucho menor en el cargo que se hacía, ya que no llegaba ni a la mitad del total del dinero entregado. Así de los 1.461 reales que Rodrigo Álvarez Becerra había recibido al final de la Junta de septiembre-diciembre de 1637, solamente 332 reales, esto es, un 22,72\%, se atribuían al pago de correos, papel sellado, portes de cartas y velas ${ }^{120}$. Aparte de estas cantidades, el escribano podía incrementar sus ingresos si se le habilitaba para la Diputación Permanente del Reino, en teoría, hasta un máximo de 441 reales anuales ${ }^{121}$. Pero en realidad, ya por la bajada o reducción del tiempo de servicio, ya por las menores necesidades materiales, el montante final nunca había alcanzado ni la mitad de lo que en principio se estimaba ${ }^{122}$.

El abono del sueldo del escribano correspondía al conjunto de las siete ciudades o a aquélla que le había nombrado por turno. Una vez ajustada esta cantidad, el Gobernador cursaba una orden dirigida a los consistorios de las cabeceras provinciales o bien a uno de ellos para que procediesen al reparto de la misma. Cuando este

\footnotetext{
${ }^{118}$ Desde el 22 de febrero de 1655 , fecha en la que ya se encontraba en Pontevedra, y hasta dar comienzo el 12 de marzo de 1655 a la Junta de de febrero-marzo de 1655, Benito Gómez Beiya, escribano nombrado por la ciudad de Betanzos, se había ocupado de redactar las cartas dirigidas a las ciudades de Santiago de Compostela y A Coruña apremiándoles a que enviaran a sus representantes, de gestionar la entrega de la documentación de las juntas y demás alajas y confeccionar el inventario de todo ello. Detalles en Antonio Eiras Roel (ed.), Actas de las Juntas..., vol. 7, págs. 531-532, 537 y 539-542.

${ }^{119}$ De los 818 días que había durado la Junta de marzo de 1709-enero de 1712, a Bernardo Álvarez Becerra sólo se le habían abonado el salario correspondiente a 556 días, pues durante el mes de agosto de 1710 se había suspendido la reunión. Asimismo se le descontaban otros 100 días durante los cuales había estado en su casa y otros 162 en los cuales no había asistido personalmente. Antonio Eiras Roel (ed.), Actas de las Juntas..., vol. 15, pág. 279.

${ }^{120}$ Antonio Eiras Roel (ed.), Actas de las Juntas..., vol. 3, pág. 215.

${ }^{121}$ Este sueldo se le había fijado en la última conferencia de la Junta de diciembre de 1635-enero de 1636. Antonio Eiras Roel (ed.), Actas de las Juntas..., vol. 2, pág. 374.

${ }^{122} \mathrm{La}$ única prueba que hemos localizado son los 165 reales que se le habían entregado a Antonio de Cea Mariño por los 6 meses que había permanecido sirviendo. Antonio Eiras Roel (ed.), Actas de las Juntas..., vol. 2, pág. 373.
} 
repartimiento se realizaba por el conjunto, se imitaba el aplicado desde la Junta de noviembre de 1636 para la recaudación de los servicios concedidos por el Reino a la Corona, para el reclutamiento de hombres para la guerra o para otras imposiciones generales; es decir, se dividía en tres tercias partes al por mayor, la primera para la de Santiago de Compostela, la segunda para las de Lugo y Ourense por mitad y la tercera para las restantes provincias ${ }^{123}$. Frente a lo anterior, la aplicación del sistema "turnario" pese a ser una decisión, como ya hemos visto, consensuada en su día por un acuerdo tácito, no estuvo exenta de algunas críticas que insistían en el fuerte gravamen que ello suponía. Este era el sentir de don Antonio de Oca, diputado de A Coruña, quien en 1651 opinaba que ahogaba económicamente a una provincia tan pequeña como la suya que afrontaba este pago por sí sola ${ }^{124}$. Otro inconveniente estribaba en el fuerte desembolso económico que para un mismo concejo suponía tener que hacer frente varias veces seguidas a este pago. La solución a esto vendría de mano de la decisión tomada en la Junta de julio de 1656 , consistente en hacer correr la vez de nombrar al escribano cuando la junta se interrumpiese y hubiese de proseguir ${ }^{125}$. Pero esta falta de liquidez no afectaba solo a urbes con un territorio exiguo o cuyos recursos económicos eran escasos, sino que en determinados instantes podía extenderse al conjunto de las mismas, que se veían forzadas a sumar el sueldo del escribano al devengado en la siguiente reunión ${ }^{126}$. Detrás de esto se encontraba también una variada casuística de retrasos injustificados ${ }^{127}$, negligencias e irregularidades por parte de los diputados. A ello aludía en 1712 Bernardo Álvarez Becerra, quien al poner en conocimiento del Gobernador la negativa de la ciudad de Mondoñedo a pagarle lo adeudado desde 1703, llamaba la atención sobre el uso fraudulento y particular de su salario ${ }^{128}$.

\footnotetext{
${ }^{123}$ Antonio Eiras Roel (ed.), Actas de las Juntas..., vol. 3, págs. 95-96. Explicación más detallada en Antonio Eiras Roel (ed.), Actas de las Juntas..., vol. 9, págs. 1120-1122

124 “El señor don Antonio de Oca, diputado de la ciudad de la Coruña, propuso su probincia hestar agraviada en los salarios de los secretarios de la Junta, aviendo de satisfacerlos por si sola quando le toque el turno, en atençión de ser la más pequeña de las siete del Reino". Antonio EIRAS RoEL (ed.), Actas de las Juntas..., vol. 6, págs. 287-288.

125 "En esta Junta se acordó que quando se ubiere de prosiguir corra el turno de nonbrar scrivano que asista a ella a la ciudad de Mondoñedo, respeto de los grandes gastos que ha tenido la de Lugo en los salarios del presente escrivano, y aver simil en otras Juntas de que aunque suspendieron corrió el turno de nonbrar scrivano". Antonio Eiras Roel (ed.), Actas de las Juntas..., vol. 7, pág. 164.

${ }^{126}$ Por ejemplo, en la Junta de febrero-marzo de 1642 las ciudades adeudaban en su conjunto al escribano 680 reales de la anterior. Antonio Eiras Roel (ed.), Actas de las Juntas..., vol. 5, pág. 126. ${ }^{127}$ El 13 de marzo de 1708 se decidió escribir a la ciudad de Santiago de Compostela urgiéndole a que abonara la parte que le correspondía en el rateo realizado a favor de Bernardo Álvarez Becerra. Antonio Eiras Roel (ed.), Actas de las Juntas..., vol. 14, pág. 449

128 “..., que por hallarse los regidores que han concurrido a las Juntas satisfechos de su ocupación non han hecho aprecio de que se diese al suplicante, antes sí, según a mi noticia es venido, usaron de las partidas repartidas y depositadas que le correspondian al suplicante, deseando quizá con nuebo motibo hazer repartimientos de los que los naturales ya tienen pagado,..." Miguel Romaní Martínez (ed.), Xuntas do Reino..., vol. 16, pág. 357.
} 
Esta incapacidad para obtener los fondos necesarios, obligaron a ensayar otras estrategias con las que responder a esta exigencia. Una de estas estrategias eventuales fue pagarle con cargo al dinero que algunos particulares adeudadaban al Reino $^{129}$. Y a fin de mitigar en lo posible las disputas y resistencias que su entrega pudiese originar, se instó al mismo escribano a que describiese cada concepto abonado con claridad. No por casualidad desde la Junta de febrero-abril de 1716 se dan de manera individualizada las cuantías que tocan a cada ciudad en todos y cada uno de los conceptos abonados ${ }^{130}$, a diferencia de como venía haciéndose hasta entonces.

Este jornal podía también verse menguado, e incluso denegado, si se consideraba que el escribano había sido negligente en algunas de las tareas que realizaba. Si extraviaba o por su culpa desaparecían los instrumentos de la escribanía, su reposición corría a su cuenta ${ }^{131}$. Más grave, si cabe por su trascendencia, resultaban aquellas acusaciones de apropiación indebida de caudales ${ }^{132} \mathrm{u}$ ocultación de algunos documentos cuya revelación hubiese acotado la junta a los días previstos. El 17 de mayo de 1689 don Juan de Carbajal, representante de Mondoñedo, censuraba la actitud de Pedro Sánchez Delgado por haber esperado hasta el primero de dicho mes para entregar un decreto del ayuntamiento de Betanzos, comunicando la designación de su nuevo diputado en sustitución de don Francisco de Puzo. Su recriminación se basaba en que si lo hubiese hecho al llegar a su poder, hubieran podido retirarse a sus casas antes del 4 de abril. Por ello se oponía a que se le pagara desde el 1 de mayo en adelante ${ }^{133}$.

Por su parte, los amanuenses que asistían al titular, eran recompensados también con cargo a las sumas distribuidas entre las provincias o en una de ellas.

\footnotetext{
${ }^{129}$ Los diputados de la Junta de enero-febrero de 1643 habían acordado emplear los 800 reales adeudados por Pascual González para pagar a Jorge das Seixas. Antonio Eiras Roel (ed.), Actas de las Juntas..., vol. 5, págs. 196-197.

${ }^{130} \mathrm{Al}$ comenzar el rateo de esta Junta, Bernardo Álvarez Becerra advertía de que “..., se previno a mí, secretario, lo executase y pusiese con distinción y claridad, para que cada una de las ciudades y sus provincianos diesen satisfación de ello en propios, arbitrios o gastos de provincia, y no los haviendo se repartan con ygualdad y sin agrabiar". Miguel Romaní MartíneZ (ed.), Xuntas do Reino..., vol. 16, pág. 130.

${ }^{131}$ Esto se le recriminaba en la Junta de junio-julio de 1716 al señalar “... que la escrivanía de plata y campanilla que tenía el Reino se a urtado de poder del presente secretario y se necesita para el servicio de él en las Juntas que se ofrecieren, y se de su obligaçión mandarlas açer, respecto que la ciudad de Santiago aún se dize estarle deviendo partida de sus salarios de la Junta de concesión de los ocho terçios, se encarga al señor don Gregorio Sanches le mande açer por quenta dellos". Miguel Romaní Martínez (ed.), Xuntas do Reino..., vol. 16, pág. 176.

${ }^{132}$ A Antonio de Cea Mariño se le reclamaban 165 reales el 23 de junio de 1636 y que ya se le habían librado el 23 de enero de 1636 por don Jacinto de Ponte y Fernán Pérez das Seixas. Antonio Eiras Roel (ed.), Actas de las Juntas..., vol. 2, pág. 447.

${ }^{133}$ Antonio Eiras Roel (ed.), Actas de las Juntas..., vol. 10, págs. 221-222.
} 
Pero, con la patrimonialización del oficio desde 1677, esta obligación pasaría de modo oficial a recaer en el escribano propietario ${ }^{134}$.

El oRIGEN GEOGRÁFICO Y EL PERFIL PROFESIONAL DE LOS ESCRIBANOS DE LAS JUNTAS Y SUS EXCUSADORES

Una primera conclusión que podemos extraer sobre el origen geográfico de los titulares y sus subalternos, siempre y cuando se nos facilita esta información, viene a corroborar que mayoritariamente son nativos del Reino de Galicia. De los treinta y seis individuos de los que sabemos su procedencia para la totalidad de los años estudiados, quince de ellos estaban asentados en A Coruña, mientras que los otros diez se repartían entre las ciudades de Betanzos, Tui, Santiago de Compostela, Lugo, Ourense y excepcionalmente Valladolid ${ }^{135}$; villas como las de Redondela y Pontevedra y comarcas naturales como el valle de Lourenzá en la provincia de Mondoñedo. Este predominio coruñés que adelantábamos al hablar de la duración y cese en el oficio, poniéndolo en relación directa con el lugar escogido en cada caso como sede prevalente de la junta, también se extiende a los excusadores. Un buen ejemplo nos lo proporcionan los secretarios propietarios Bernardo Álvarez Becerra y su sucesor Bernardo del Río, quienes entre 1705 y 1834 eligieron para reemplazarles a seis escribanos coruñeses y a un pontevedrés, dependiendo de donde comparecían ${ }^{136}$. Por su parte, la contribución de efectivos por las otras capitales provinciales obedece, como hemos visto, a la puesta en marcha de la modalidad de nombramiento por turno en la que se escogía a los escribanos de sus respectivos concejos. La excepción a esta norma la representan Alonso Villarino y Viveiro, vecino del valle de Lourenzá, quien había ocupado la escribanía en la Junta de abril de 1664 por la ciudad de Mondoñedo al carecer su escribano de concejo del título de escribano real ${ }^{137}$, y Gregorio Rodríguez, escribano del ayuntamiento de Redondela, quien había sido nombrado por don

\footnotetext{
${ }^{134}$ Aunque ya en la Junta de julio de 1679 se le había recordado a Rodrigo Álvarez Becerra que a él le correspondía pagar al escribiente, será en la de julio-diciembre de 1691 cuando, a propuesta de Antonio de Prado, diputado de A Coruña, se ratifique mediante acuerdo. Antonio Eiras Roel (ed.), Actas de las Juntas..., vol. 11, págs. 110-111.

${ }^{135}$ Se trataba de Diego de Vera quien ejercía como escribano del número de esta ciudad, de sus obras y bosques, así como contador de la misma. Había acudido a la Junta de julio de 1629 como escribano de la comisión que el monarca había dado al licenciado José González, fiscal del Consejo Real, para la obtención de un servicio del Reino y había sido designado como secretario de la misma por los diputados. Antonio Eiras Roel (ed.), Actas de las Juntas..., vol. 1, págs. 410-413.

${ }^{136}$ En la Junta celebrada en Pontevedra entre febrero-agosto de 1705, Bernardo Álvarez Becerra había sido reemplazado desde el 23 de mayo hasta el 23 de junio de ese año por Francisco Antonio Vélez, escribano del número de la villa de Pontevedra.

${ }^{137}$ Antonio Eiras Roel (ed.), Actas de las Juntas..., vol. 7, pág. 703.
} 
Benito Fernández, diputado de Tui, al llegar a dicha villa para la Junta de septiembre-octubre de $1666^{138}$.

Una tónica común a todos estos individuos desde el punto de vista de su perfil laboral, radica en el hecho de formar parte de los cuadros de profesionales de la escritura adscritos a cuatro ámbitos de actuación. El más numeroso de todos ellos, diecisiete, lo formaban los escribanos reales quienes por tres veces copan alguna de las escribanías numerarias y del consistorio, tales como Pedro Rodríguez de Leis y Rodrigo Álvarez Becerra en A Coruña y Gregorio Rodríguez en Redondela, o llevan cuenta de todo lo vinculado con la administración de la sisa, millones y guerra, como Francisco Alfaia Troncoso en Tui. Después de ellos están aquellos otros que a su condición de escribanos reales unen la del ayuntamiento, seguidos de cerca por los numerarios. Y cierra la lista, con apariciones esporádicas, los receptores y escribanos de asiento de la Real Audiencia de Galicia.

\section{BiBLIOGRAFÍA}

Actas de las Juntas Generales de Álava, Juntas Generales de Álava, 1994.

Arquivos de Galicia [en línea], disponible en <http://arquivosdegalicia.xunta.es/portal/ arquivo-historico-provincial-de pontevedra/content/actividades/actualidad/actual_0002. html?lang=es $>$ [Consulta: 02/12/2014].

Artaza Montero, Manuel María de, Rey, reino y representación: la Junta General del Reino de Galicia (1599-1834), Madrid, Consejo Superior de Investigaciones Científicas, 1998.

Artaza Montero, Manuel María de, A Xunta do Reino de Galicia no final do Antigo Réxime (1775-1834), A Coruña, Fundación Pedro Barrié de la Maza, 1993.

Caveda Nava, José y otros, La Junta General del Principado, Gijón, Silverio Cañada, 1989.

Domínguez Ortiz, Antonio, "La venta de cargos y oficios públicos en Castilla y sus consecuencias económicas y sociales", en Antonio Domínguez Ortiz, Instituciones y sociedad en la España de los Austrias, Barcelona, Ariel, 1985, págs. 145-183.

Eiras Roel, Antonio, Actas de las Juntas del Reino de Galicia, Santiago de Compostela, Dirección Xeral do Patrimonio Histórico e Documental, 1995-2005, vols. 1-15.

Eiras Roel, Antonio, "Introducción histórica: las Juntas del Reino de Galicia en el período protoinstitucional, 1599-1629", en Antonio Eiras Roel (ed.), Actas de las Juntas del Reino de Galicia, Santiago de Compostela, Dirección Xeral do Patrimonio Histórico e Documental, 1995, vol. 1, págs. 5-55.

Fernández Suárez, Gonzalo Francisco, "Una primera aproximación a los escribanos del concejo de Lugo entre los siglos XVI-XVIII", en Carlos Baliñas Pérez, Gonzalo Francisco Fernández Suárez (eds.), Sur Urbem: historia, sociedade e cultura da cidade, Santiago de Compostela, Universidade de Santiago de Compostela, 2012, págs. 143-159.

Fernández Vega, Laura, "Orígenes y antecedentes, naturaleza y función de las juntas del Reino de Galicia, hasta la consecución del voto en Cortes", en Antonio Eiras Roel (ed.), Actas de

\footnotetext{
${ }^{138}$ Antonio Eiras Roel (ed.), Actas de las Juntas..., vol. 8, pág. 488.
} 
las Juntas del Reino de Galicia, Santiago de Compostela, Dirección Xeral do Patrimonio Histórico e Documental, 1995, vol. 1, págs. 59-85.

Fernández-Villamil Alegre, Enrique, Juntas del Reino de Galicia: historia de su nacimiento, actuaciones y extinción, 3 vols., Madrid, Instituto de Estudios Políticos, 1962.

Friera Álvarez, Marta, La Junta General del Principado de Asturias a fines del Antiguo Régimen (1760-1835), Oviedo, Junta General del Principado de Asturias, 2003.

Menéndez González, Alfonso, Élite y poder: la Junta General del Principado de Asturias, 1594-1808, Oviedo, Instituto de Estudios Asturianos, 1992.

Murguía, Manuel, Galicia, Vigo, Edicións Xerais de Galicia, 1982, 2 vols.

Pérez Costanti, Pablo, Notas viejas galicianas, Vigo, Imprenta de los Sindicatos Católicos, 1925, 3 vols.

Romaní Martínez, Miguel, Xuntas do Reino de Galicia: actas, Santiago de Compostela, Dirección Xeral de Patrimonio Cultural, 2008-2010, vols. 16-27.

Tuero Bertrand, Francisco, La Junta General del Principado de Asturias, Gijón, Ayalga, 1978.

Varela Pardo, María del Rosario Matilde y Rama Patiño, María Luz, "Informe sobre la documentación de juntas del Reino catalogada en los archivos públicos de las siete antiguas ciudades del Reino de Galicia”, en Antonio Eiras Roel (ed.), Actas de las Juntas del Reino de Galicia, vol. 1, Santiago de Compostela, Dirección Xeral do Patrimonio Histórico e Documental, 1995, págs. 87-157.

Vicetto, Benito, Historia de Galicia, Ferrol, 1873, vol. 7. 
